\title{
Geneza oraz ewolucja ołtarza ramowego na Śląsku i w twórczości artystów zwiq̨zanych z ośrodkiem artystycznym w Bardzie ${ }^{1}$
}

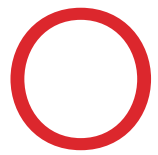

łtarz, będąc podstawowym elementem wyposażenia kościelnego, obecny jest powszechnie w sztuce sakralnej. Obok pełnienia funkcji kultowych stanowi świadectwo ewolucji myśli teologicznej oraz zachodzących na przestrzeni wieków procesów artystycznych. Późnobarokowa i rokokowa sztuka na Śląsku nie była pod tym względem wyjątkiem, a licznie zachowane do naszych czasów dzieła i przekazy archiwalne pozwalają prześledzić szeroki wachlarz przemian zachodzących w „małej architekturze” tego czasu. Kanwę niniejszego artykułu stanowi grupa nastaw atektonicznych - ramowych, szczególnie licznie reprezentowana na Śląsku przez dzieła artystów działających bądź związanych z osiemnastowiecznym 
ośrodkiem artystycznym w Bardzie Śląskim. Nie rości on sobie jednak ambicji ujęcia wszystkich obiektów tej grupy, a jedynie istotnych dla rozwoju zjawiska.

Ośrodek bardzki - funkcjonujący w peryferyjnej osadzie przy granicy Śląska i Hrabstwa Kłodzkiego - stanowił swoisty fenomen w dziejach sztuki śląskiej². Niewielka miejscowość, położona w pobliżu ważnego dla regionu kościoła pielgrzymkowego, należała od średniowiecza do 1810 roku do cystersów z Kamieńca Ząbkowickiego. Około 1700 roku struktura społeczna Barda uległa zmianie. O ile wcześniej przedstawiciele zawodów artystycznych byli rzadkością, bądź nie pojawiali się wcale, o tyle na przestrzeni XVIII wieku miasteczko stało się siedzibą licznych rzemieślników - przede wszystkim rzeźbiarzy. Tylko w połowie tego stulecia w Bardzie działało siedmiu w pełni wykształconych przedstawicieli rzeźbiarskiej profesji ${ }^{3}$, co jednak nie oznaczało istnienia tak wielu odrębnych pracowni. Pewni możemy być funkcjonowania w tym czasie jedynie dwóch atelier, prowadzonych przez Johanna Heinricha Hartmanna (urodzonego przed 1714 rokiem $^{4}$, zmarłego po 1784 roku $^{5}$ ) oraz Andreasa Ludwiga Jäschkego (1701-17846). Pozostali rzeźbiarze zapewne w większości pełnili rolę pomocników u wspomnianych mistrzów. Tym niemniej istnieją realizacje, wykazujące cechy stylowe rzeźb Hartmanna czy Jäschkego, lecz zdradzające przy okazji silnie indywidualne komponenty formalne. Pozwala to przypuszczać, że także niektórzy z mniej znanych artystów prowadzili w ograniczonym zakresie działalność na własną rękę.

\footnotetext{
2 Z najważniejszych publikacji wspominających o istnieniu ośrodka rzeźbiarskiego w Bardzie wymienić należy: OSTOWSKA 1969, s. 25-26; CHRZANOWSKI 1980, s. 81-91; CHRZANOWSKI 1981, s. 81-102; KALINOWSKI 1986, s. 246-249; KOLBIARZ 2011A, passim; KOLBIARZ 2012, passim. Byli to: Johann Heinrich Hartmann, Andreas Ludwig Jäschke, Gottfried Kommerthor, Johann Georg Kornauer, Franz Michäel Peltz, Joseph Strauss oraz Ignatz Thör. Zob.: AAWr., księga metrykalna, sygn. 108c. Zob. także: KOLBIARZ 2012, s. 255. Do tej grupy nie należał, wbrew sugestiom Tadeusza Chrzanowskiego, Josef Michael Steiner (zob.: CHRZANOWSKI 1981, s. 92-93), który był malarzem działającym w Bardzie (zob.: APBar. księga metrykalna, Trauungs Buch bei den Pfarrkirche zu Wartha vom Jahren 1765, bis ult. 1835, brak paginacji stron. Wpisy pod datami: 25 stycznia 1774 roku; 3 lutego 1784 roku; 16 listopada 1784 roku) oraz w Ząbkowicach Śląskich (zob. AAWr., księga metrykalna, sygn. 478dd).

4 Niestety wpisy do ksiąg metrykalnych w Bardzie zawierają lukę pomiędzy 1698 i 1711 r., a regularne wpisy po tej przerwie zaczynają się dopiero w 1714 r. Zob.: AAWr., księgi metrykalne, sygn. 108a i 108 b.

5 Kiedy 16 listopada 1784 roku jego córka brała ślub z malarzem Franzem Steinerem, artysta jeszcze żył. Zob.: APBar., bez sygn., Trauungs=Buch der Kirche ze Wartha aus dem Franckensteinen Archipresbyteriat, [wpis pod data]].

6 APBar., bez sygn., Begrabnisbuch 1766-1803, s. 124.
} 
Skład osobowy bardzkiego ośrodka artystycznego uzupełniali stolarze ${ }^{7}$, malarze (głównie sztafirerzy) $^{8}$, pozłotnicy ${ }^{9}$ i murarze ${ }^{10}$. Wszyscy ci przedstawiciele różnych profesji artystycznych - doskonale dopełniających się w procesie wytwarzania sprzętów kościelnych - niejednokrotnie współpracowali ze sobą. Mogli tworzyć zespoły pozwalające na realizację zamówienia od początku do końca, bez konieczności sięgania po artystów z innych miejscowości. Jedynie brak sprawnego malarza sztalugowego zmuszał zleceniodawców do częstego posiłkowania się rzemieślnikami z zewnątrz. Kiedy jednak retabula w całości były rzeźbione i pozbawione malowideł, artyści z ośrodka bardzkiego mogli być samowystarczalni ${ }^{11}$. Oczywiście oprócz takiego modelu produkcji artystycznej funkcjonowała zwyczajowa współpraca z rzemieślnikami zamiejscowymi, szczególnie w przypadku zleceń odległych od miejscowości pielgrzymkowej.

Począwszy od schyłku lat 40. aż po lata 80. XVIII wieku bardzcy artyści zdominowali rzeźbiarską produkcję na terenie księstwa ziębickiego. Silnie zaznaczyli swoją obecność także na sąsiednich terytoriach nyskiego księstwa biskupiego oraz Hrabstwa Kłodzkiego, sporadycznie działając również na Broumowsku oraz Śląsku Górnym i Opawskim ${ }^{12}$. Przybliżony zasięg terytorialny ich działalności rozpościerał się od Wrocławia na północy ${ }^{13}$ po Lewin Kłodzki ${ }^{14}$ na południu oraz od Dzierżoniowa

Np.: Benedict Bartsch, Franz Czada, Anton Güttler, Franz Wudretzky. Zob.: AAWr., księga metrykalna, sygn. 108c.; Archiwum parafialne w Bardzie, księga metrykalna, Trauunngs Buch bei den Pfarrkirche zu Wartha vom Jahren 1765, bis ult. 1835; Tamże, Begrabnisbuch 1766-1803.

8 Np.: Joseph Rose, Joseph Steiner, Franz Steiner. Zob.: AAWr., księga metrykalna, sygn. 108c.; APBar., księga metrykalna, Trauunngs Buch... [1765-1835].

9 Np.: Georg Berst. Zob.: APBar., księga metrykalna, Begrabnisbuch 1766-1803.

10 Np.: Dominicus Jäschke, Ignatius Niesel, Andreas Jacob. Zob.: APBar., księga metrykalna, Trauunngs Buch... [1765-1835]; Tamże, Begrabnisbuch 1766-1803.

11 Dla przykładu ołtarze boczne $(1772,1773)$ w Lewinie Kłodzkim wzniesione przez Johanna Heinricha Hartmanna, sztafirowane były przez Josepha Rose. Patrz: Katalog rzeźby 1987, s. 131.

12 Więcej na temat funkcjonowania ośrodka artystycznego w Bardzie, zob.: SCHWETER 1922, op. cit., s. 432-433; CHRZANOWSKI 1980, s. 46-47, 78-91; KALINOWSKI 1986, s. 246-249; KOLBIARZ 2011A, s. 119-121; KOLBIARZ 2012, s. 253-275.

13 Z Andreasem Ludwigiem Jäschke i jego warsztatem wiązać należy pozbawione dotychczas atrybucji sprzęty kościoła parafialnego we Wrocławiu-Leśnicy: ołtarz główny (1742-1743) oraz parę bocznych (1750). Datowanie za: Die Kunstdenkmäler 1934, s. 180. Boczne retabula zostały częściowo przekształcone po 1945 roku. Ich wystrój rzeźbiarski przemieszano z rzeźbami niepochodzącymi z pracowni Jäschkego. Wymontowane z nastaw, główne dla ołtarzy przedstawienia Piety oraz św. Jana Nepomucena zawieszono na ścianach kościoła.

14 Para ołtarzy bocznych $(1772,1773)$ z kościoła parafialnego w Lewinie Kłodzkim wykonana została w pracowni Johanna Heinricha Hartmanna. Późniejsze z retabulów potwierdza kontrakt z bardzkim artystą. Zob.: KÖGLER 1841, s. 430; Katalog rzeźby 1987, s. 131. 
i Ujazdu Górnego na zachodzie ${ }^{15}$ po Opawicę na wschodzie ${ }^{16}$. Jednocześnie związany pośrednio z Bardem i działający we Wrocławiu Leopold, względnie August Leopold Jäschke ${ }^{17}$ - być może będący kuzynem wspomnianego Andreasa Ludwiga - zyskał czołową pozycję w mieście stołecznym regionu.

Powodzenie zawodowe bardzkich artystów mogło wynikać z kilku czynników. W Bardzie nie istniały cechy rzemieślnicze, co było sytuacją zrozumiałą, biorąc pod uwagę wielkość osady i jej zależność od kamienieckich cystersów. Znosiło to automatycznie obostrzenia dotyczące wielkości składu osobowego warsztatów, pozwalając na swobodne rozbudowywanie pracowni w momencie większego natężenia prac. Pomimo braku cechów działający w Bardzie rzeźbiarze posiadali pełne prawa kształcenia uczniów i czeladników, zgodnie z pryncypiami obowiązującymi w ramach rzemieślniczych gildii ${ }^{18}$. Nie byli dzięki temu wykluczeni z rynku zawodowego regionu. Dodatkowo ścisły związek Barda z „białymi mnichami” z Kamieńca Ząbkowickiego, a także Henrykowa oznaczał uprzywilejowanie tamtejszych artystów w dostępie do licznych zleceń zakonnych. Jak się można domyślać decydujące znaczenie miał właśnie brak organizacji cechowych w połączeniu $\mathrm{z}$ mecenatem cysterskim oraz

15 Centralną część ołtarza - z tabernakulum i bramkami - w kościele św. Jerzego w Dzierżoniowie wiązać należy z Andreasem Ludwigiem Jäschkem (3. ćwierć XVIII wieku). Bardzki artysta uzupełnił plastyczną aranżację prezbiterium utworzoną w trzech zasadniczych etapach. Najpierw, w latach 1615-1616 wzniesiony został monumentalny ołtarz piętrzący się na wschodniej ścianie świątyni. Następnie w 1719 roku rozbudowane zostały skrzydła, opinające poligonalne zamknięcie budowli. Zob.: SCHWEDOWITZ 1909, s. 21-22, 45-46; KACZMAREK/BRZEZIŃSKI 2010, s.107-109. Dekorację rzeźbiarską drugiej fazy ostrożnie wiązać należy z osobą Tobiasa Stahlmayera, artysty działającego w pobliskiej Świdnicy, tworzącego pod wyraźnym wpływem Georga Leonharda Webera. Po około połowie stulecia całe przedsięwzięcie zakończył Jäschke, dodając tabernakulum pełniące optyczną rolę lekko wysuniętego do przodu parawanu, częściowo przysłaniającego centralną część starszej realizacji. Obecnie brakuje przedstawień śś. Joachima i Anny, flankujących niegdyś tabernakulum. Z kolei ołtarz główny do kościoła cysterskiego w Ujeździe Górnym wykonał w 1787 roku Johann Nepomucen Hartmann za 105 Thl. Zob. JUNGNITZ 1885, s. 228.

16 Niemal kompletny wystrój kościoła w Opawicy (ok. 1772) zazwyczaj łączony jest w literaturze z Josephem (lub Johannem Nepomucenem) Hartmannem. Zob.: Grundriss eines 1933, s. 143; Katalog zabytków 1961B, s. 64-65; CHRZANOWSKI/KORNECKI [b.r.w.], s. 300; KALINOWSKI 1986, s. 247. Jednakże archiwalia mówią jedynie, że prace wykonane zostały przez nieokreślonego rzeźbiarza z Barda (Zob. WOLNÝ 1863, s. 329-330). Stylistyka dzieł rzeczywiście wskazuje na przedstawiciela dynastii rzeźbiarskiej Hartmannów, ale w 1772 Joseph rezydował już w Nysie, a Johann Nepomucen był jeszcze pomocnikiem w pracowni ojca. W tej sytuacji opawickie zlecenie należy wiązać z Johannem Heinrichem.

17 UHLHORN 1927, s. 73; Grundriss eines 1933, s. 145. Na kontraktach prac dla klasztoru w Henrykowie artysta posługiwał się wyłącznie jednym imieniem: Leopold. Zob.: AAWr, sygn. VB6s.

18 Dla przykładu pierwszy stopień edukacji w miejscowości pielgrzymkowej trwał siedem lat. Przyjęcie kandydata na rzeźbiarza poświadczane było umową spisywaną pomiędzy opiekunami, ręczącymi za młodzieńca, a mistrzem. Po pomyślnym ukończeniu nauki czeladnik otrzymywał lehrbrief, gwarantujący możliwość odbycia wędrówki czeladniczej. Zob.: PATZAK 1930, s. 67-68. 
pielgrzymkowym charakterem samego miasteczka - do którego przybywali liczni pątnicy, a wśród nich potencjalni zleceniodawcy - stanowiło okoliczności sprzyjające powołaniu prężnego ośrodka artystycznego właśnie w Bardzie, nie zaś w pobliskich miastach: Ząbkowicach Śląskich czy Ziębicach.

Jednocześnie początek wielkiej prosperity bardzkiego ośrodka, przypadający na przełom lat 40. i 50. XVIII wieku, zbiegł się z wyraźnym kryzysem rynku rzeźbiarskiego na Śląsku. Najważniejsze dotychczas w regionie środowiska artystyczne przeżywały regres wynikający z wymierania, bądź migracji rzemieślników. Toczące się kilkanaście lat wojny śląskie i uszczuplenie zaplecza finansowego kościoła katolickiego po przejściu Śląska pod panowanie Prus sprawiły, że koniunktura na dzieła rzeźbiarskie spadła i miasta nie były już tak atrakcyjne dla nowych artystów, jak na początku stulecia. Około 1750 roku Wrocław opuścili bądź zmarli: Franz Joseph Mangoldt, Johann Georg Urbansky i Johann Albrecht Siegwitz. W Świdnicy żaden z młodych rzeźbiarzy nie osiągnął pozycji zbliżonej do zajmowanej wcześniej przez Johanna Georga Webera. W Nysie zmarli wiodący prym Anton Jörg (1758) i Johann Georg Schenck. Kłodzko, sąsiadujące bezpośrednio ze Śląskiem, regres dotknął już wcześniej, kiedy na przestrzeni trzeciej dekady XVIII wieku z miasta wyjechali Michael st. Klahr i Michael Kössler, a później (1746) życie zakończył Carl Sebastian Blak (Flacker, Plag). Konkurencji dla Barda nie stanowiły mniejsze miasta regionu: Dzierżoniów, Ząbkowice Śląskie, Strzelin, czy Ziębice, skromnie reprezentowane w tym czasie przez pojedynczych artystów o lokalnym znaczeniu. Nawet, jeśli w wyjątkowych przypadkach prowadzili ożywioną działalność (np. Michael młodszy Klahr w przygranicznym Lądku Zdroju Lądku Zdroju, czy liczni rzeźbiarze pracujący dla opactwa w Krzeszowie) nie sięgała ona zbyt daleko poza region, do którego należała miejscowość. W tej sytuacji jedynie nielicznym miastom śląskim, takim jak Jelenia Góra, Głogów i Opawa, udało się utrzymać ponadregionalny zasięg oddziaływania. Ich odległe położenie sprawiło jednak, że zazwyczaj nie współzawodniczyły bezpośrednio z Bardem.

Bardo Śląskie natomiast, powiązane z cystersami kamienieckimi oraz henrykowskimi, położone na jednym z głównych szlaków handlowych, było celem licznych pielgrzymek regularnie przybywających zarówno ze Śląska, jak i z Czech. Dzięki temu stworzyło warunki dla zawodowej prosperity, pomimo niesprzyjających okoliczności polityczno-gospodarczych. Artyści tam pracujący, przetrwawszy krótkotrwały kryzys połowy stulecia, wypełnili w znacznej mierze lukę po sąsiednich ośrodkach. Stali się głównymi wykonawcami ostatniej nowożytnej ofensywy artystycznej, prowadzonej przez kościół katolicki w południowo-wschodniej części Dolnego Śląska, głównie przez konwenty w Henrykowie i Kamieńcu 
Ząbkowickim oraz wrocławską kapitułę. Ich intensywna działalność i szeroki zasięg oddziaływania skupia - niczym w soczewce - istotne problemy dotyczące ówczesnej „małej architektury”.

Ponad stuletnia działalność ośrodka bardzkiego pozwala na prześledzenie ewolucji struktur ołtarzowych w szerokim zakresie, od form właściwych dojrzałemu barokowi, po rokoko z elementami klasycyzmu. Obok retabulów architektonicznych znaczna część produkcji tamtejszych artystów dotyczyła nastaw atektonicznych. Tadeusz Chrzanowski już ponad trzydzieści lat temu zwrócił uwagę na licznie występujące w okolicach Barda Śląskiego dzieła należące do tego typu ${ }^{19}$. Pomimo znacznej różnorodności form ich charakterystyczną cechą jest redukcja struktury retabulum do ramy ujmującej obraz i niezależne umocowanie mensy względem samej nastawy, często powiązanych ze sobą jedynie optycznie. Ustalenia Chrzanowskiego powtórzył Konstanty Kalinowski w syntezie barokowej rzeźby śląskiej, utrwalając ich znacznie w historii sztuki ${ }^{20}$.

Ołtarze wyszczególnione przez Chrzanowskiego posiadają zróżnicowane struktury, ukazujące znaczną niejednorodność, ale przynależą do typu ramowego. W przywoływanej, polskojęzycznej literaturze brak jest rozbudowanej refleksji nad typologią atektonicznych nastaw. Odnosząc się do literatury niemieckojęzycznej wyszczególnić można kilka odmian ołtarza ramowego. Należą do nich przede wszystkim retabula: ornamentalne (np. małżowinowo-chrząstkowe, akantowe, rocaillowe, utworzone z obłoków, itp.), wolutowe i kombinowane z baldachimem ${ }^{21}$.

Pierwowzoru nastawy ramowej na Śląsku długo upatrywano w ołtarzu głównym kościoła pielgrzymkowego w Bardzie Śląskim (1715), bądź retabulum z kościoła pojezuickiego w Nysie $(1691)^{22}$. Niestety, drugi ze wspomnianych obiektów zachowany jest fragmentarycznie, co nie pozwala na pełną rekonstrukcję pierwotnej koncepcji nastawy. Jednakże nawet jego obecny stan sugeruje, że dzieło nie należało do ołtarzy ramowych. Nie posiada żadnej ramy ani struktury otaczającej rzeźby, co wskazuje, że jest odmianą retabulum ściennego w typie ołtarza rzeźbiarskiego ${ }^{23}$. Niezależnie od typologicznego przyporządkowania zabytku nyskiego, niedawna publikacja Ryszarda Hołowni zmodyfikowała wcześniejsze ustalenia, wskazując na mający powstać

CHRZANOWSKI 1981, s. 90-93.

KALINOWSKI 1986, s. 246.

W zakresie typologii ołtarzy ramowych szczególnie, zob.: SCHEMPER-SPARHOLZ 1998, s. 59.

Na temat nastaw niearchitektonicznych, zob. także: HAMPREL/AQUILAS 1999; KERN 2011.

CHRZANOWSKI 1981, s. 90; KALINOWSKI 1986, s. 246.

Por.: SCHEMPER-SPARHOLZ 1998, s. 58-60. 


\section{Rzeźbiarz śląski(?), ottarz główny, kościół św. Jakuba, \\ Nysa, 1677-1679. Stan sprzed 1894 roku. Fot. ze zbiorów autora}
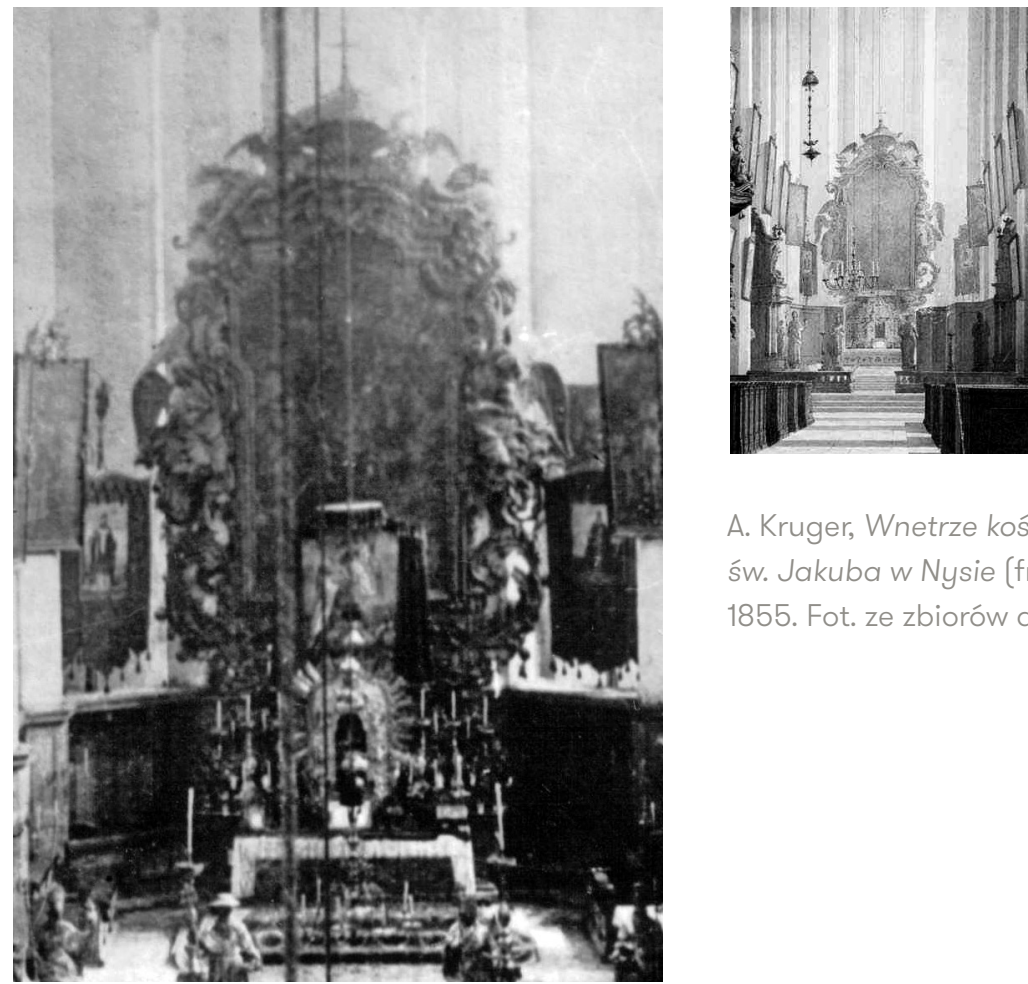

A. Kruger, Wnetrze kościoła św. Jakuba w Nysie (fragment), 1855. Fot. ze zbiorów autora

wcześniej, nieistniejący już ołtarz główny kościoła św. Jakuba w Nysie. Owe rewolucyjne stwierdzenia wrocławski badacz oparł na zestawieniu fotografii, ukazującej prezbiterium nyskiej świątyni przed przeprowadzeniem purystycznej regotycyzacji (u schyłku XIX wieku), z wiadomościami archiwalnymi ${ }^{24}$, częściowo pokrywającymi się ze spisaną w 1698, a opublikowaną w 1905 roku historią nyskiej świątyni² ${ }^{25}$. Zawierają one liczne informacje na temat gruntownej i spójnej ideowo modernizacji wnętrza, której wstępny etap w latach 1677-1679 wykonany został na polecenie kardynała Fryderyka von Hessen-Darmstadt, a dokończony w latach 80. XVII wieku ${ }^{26}$.

Ustalenia Hołowni zmieniają diametralnie genezę ołtarzy ramowych na Śląsku, a biorąc pod uwagę tak wczesne datowanie - w Europie Środkowej w ogóle. Ołtarz widoczny na zdjęciu zaskakuje bowiem niezwykłym nowatorstwem i dojrzałością formy, wyprzedzając podobne realizacje w regionie o kilkadziesiąt lat. Gdyby

24 HOEOWNIA 2008, s. 146-147. Dodatkowych informacji ikonograficznych dostarcza obraz autorstwa A. Krugera z 1855 roku.

25 PEDEWITZ 1905. Dodatkowym źródłem na temat niezachowanego już zespołu barokowych ołtarzy jest praca Augusta Kastnera, który miał dostęp do archiwaliów, a jednocześnie do istniejących jeszcze zabytków. Zob.: KASTNER 1848.

26 HOŁOWNIA 2008, s. 146-148, 156-159. 
nie opis Pedewitza z 1682 roku, odnotowujący zasadnicze elementy ołtarza, można by zakładać27, że fotografia archiwalna ukazuje obiekt, który uległ zasadniczym przekształceniom w późniejszym czasie. Na przełomie 3. i 4. ćwierci XVII wieku trudno bowiem na północ od Alp o akantowe ołtarze ramowe $\mathrm{z}$ lecącymi aniołami podtrzymującymi obraz. Wczesnym przykładem retabulów z aniołami asystującymi obrazowi jest para nastaw przytęczowych kościoła pielgrzymkowego Maria Plain, wzniesionych w latach 1673-1674 według projektów Giovanni Antonia Dario ${ }^{28}$. Prezentują one jednak odmienną koncepcję, stanowiąc parafrazę słynnych ołtarzy Gianlorenzo Berniniego z kościoła Santa Maria del Popolo w Rzymie (około 1660), z figurami anielskimi stojącymi, nie zaś unoszącymi się po bokach obrazu. Podobnie jest w przypadku dzieła Michaela Zürna z kościoła klasztornego w Kremsmünster (1682-1686) ${ }^{29}$, jeszcze bliższego rzymskim pierwowzorom.

Nazwiska projektanta i wykonawcy nyskiego ołtarza pozostają zagadką. Hołownia podkreśla włoską orientację stylową barokizacji nyskiej świątyni ${ }^{30}$, którą nadzorował ceremioniarus Fryderyka von Hessen-Darmstadt, mediolańczyk z pochodzenia - Giovanni Batista de Angelis. Nic jednak nie wiadomo na temat jego umiejętności projektowania dzieł sztuki. Wiemy natomiast, że wspomagał go nyski kanonik Tobias Constantin Hancke, nazywany przez ówczesnego proboszcza Johanna Felixa Pedewitza „dobrym architektem” ${ }^{31}$. Z jego dzieł w kościele nyskim, raczej niewielkich skalą, wymienianych w archiwaliach (m.in. Grób Święty, szkatułki na relikwie), zachowały się cztery z sześciu konfesjonałów (1686-1687) o klarownej i klasycyzującej, architektonicznej formie ${ }^{32}$. Z przekazów archiwalnych wiadomo, że kanonik inspiracje czerpał bezpośrednio z Italii, do której miał okazję podróżować. Trudno jednak na tak wątłej podstawie rozstrzygać czy był autorem konceptu ołtarza głównego, który bynajmniej nie posiadał wyłącznie włoskiej proweniencji stylowej i łączył najnowsze zdobycze tamtejszej sztuki (motyw lecących aniołów) $\mathrm{z}$ atektonicznością ołtarzy akantowych, wyrastającą z doświadczeń zaalpejskich. Wykonawca nyskiej nastawy musiał również przejawiać nieprzeciętny talent. Chociaż jakość fotografii nie pozwala odgadnąć szczegółów, sam sposób zakomponowania figur anielskich - dynamiczny i swobodny, z wyrazistą gestykulacją oraz obrotem ciała wokół własnej osi - zdradza wprawną rękę i odpowiada założeniom rzeźby dojrzałego baroku.

Zaskakujące jest, że ołtarz z kościoła św. Jakuba w Nysie nie odegrał żadnej roli w rozwoju rzeźby śląskiej ostatniej ćwierci XVII wieku. Przez kilka dziesięcioleci 


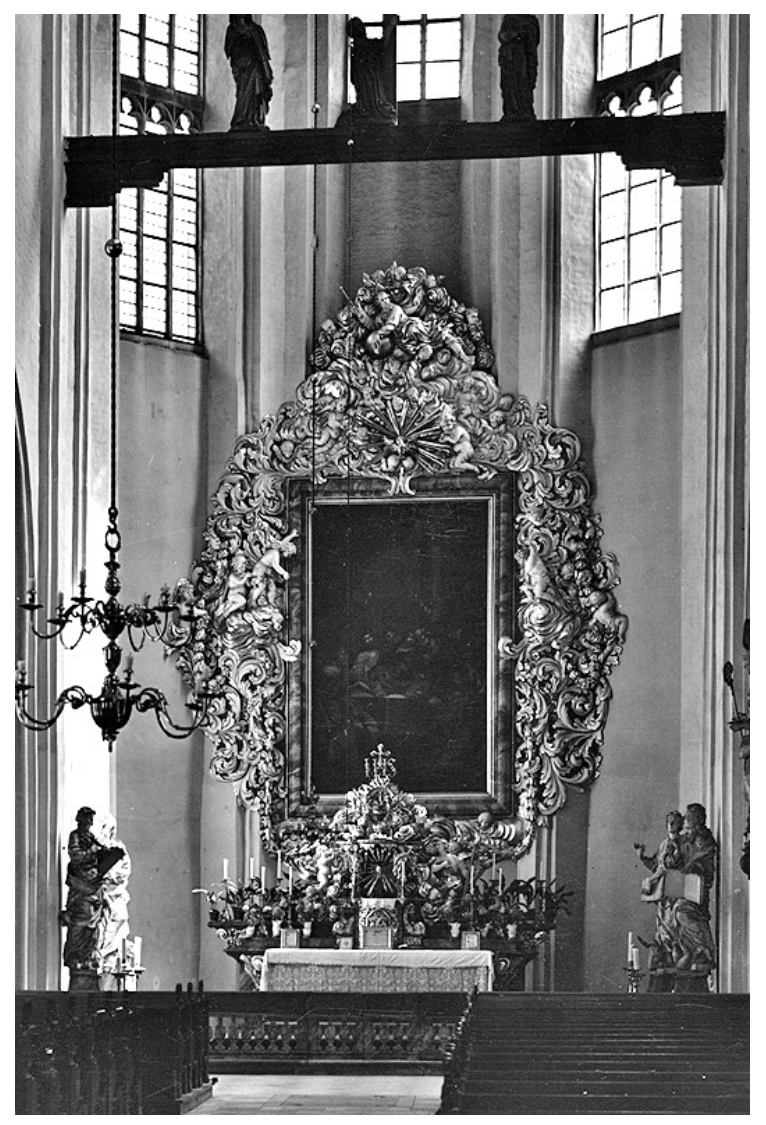

Sulpicius Gode (atryb.),

ołtarz główny,

kościół Bożego Ciała,

Wrocław, 1699.

Stan sprzed 1945 roku.

Fot. Herder Institut

Marburg, sygn. 129078

brak było dzieł choćby nawiązujących do tej realizacji, a ewolucja zarówno ołtarzy ramowych, jak i motywu anielskiego, kształtowana była przez odmienne tradycje artystyczne.

Równoległą linię rozwoju retabulów ramowych na Śląsku rozpoczyna ołtarz główny z kościoła Bożego Ciała we Wrocławiu, pomijany dotąd w tym kontekście przez badaczy. Dzieło to - prezentujące typ retabulum ramowego ornamentalnego - wykonane w technice narzutu, zachowane jest w niepełnym stanie. Przedwojenne zdjęcia ukazują jednak kompletną strukturę, składającą się dwóch odrębnych części: mensy z późniejszym tabernakulum oraz osobnej ramy akantowej nałożonej na ścianę. Wzniesienie ołtarza w 1699 roku $^{33}$ łączyć należy z osobą Sulpiciusa Godego ${ }^{34}$, flamandzkiego artysty czynnego we Wrocławiu na przełomie XVII i XVIII wieku. Ów dopiero odkrywany artysta $\mathrm{w}$ świetle najnowszych badań wyrasta na ważną postać

33 Datowanie za: KNOBLICH 1862, s. 128. W polskojęzycznej literaturze spotkać można błędne datowanie na ok. 1730 r. Por.: DEHIO 2006, s. 980.

34 Atrybucji obiektu Godemu dokonał dr hab. Michał Wardzyński, któremu serdecznie dziękuję za podzielenie się spostrzeżeniami. 
wrocławskiej rzeźby tego czasu ${ }^{35}$. Notowany w stolicy regionu co najmniej od $1680^{36}$ do $1721 \mathrm{roku}^{37}$, przybył na Śląsk ze znajomością ówczesnej rzeźby flamandzkiej. Jego wpływ widoczny jest $\mathrm{w}$ realizacjach wiązanych $\mathrm{z}$ dominującym wówczas we Wrocławiu rzeźbiarzem i przedsiębiorcą rzeźbiarskim - Johannem Christophem Königiem. Zachowane archiwalia potwierdzają, iż rodziny obu artystów utrzymywały bliskie kontakty i możliwe ${ }^{38}$, że więzy łączyły ich również na polu zawodowym. Specyfiką działalności Königa było bowiem zawiązywanie przy niektórych realizacjach krótkotrwałych spółek $\mathrm{z}$ innymi rzeźbiarzami dysponującymi własnymi warsztatami i być może Gode bywał jednym z jego współpracowników. Jeżeli nawet tak nie było, König sięgał po modusy formalne typowe dla Flamanda (widoczne w niektórych rzeźbach ołtarzy głównych kościołów: augustiańskiego w Żaganiu z 1695 roku, św. Wawrzyńca w Strzelcach Opolskich z lat 1698-1700, czy parafialnego w Kuniowie z lat 90. XVII wieku) ${ }^{39}$.

Gode, projektując retabulum do kościoła Bożego Ciała, dokonał kompilacji dostępnych wzorców dotyczących akantowych ołtarzy oraz epitafiów. Geneza formalna akantowej ramy otaczającej obraz ołtarzowy wywodzi się z zaalpejskiej tradycji rozwoju ołtarzy atektonicznych, które w drugiej połowie XVII wieku przyjmują formę Akanthusaltar i mają swoją bogatą reprezentację $e^{40}$. Na Śląsku ważną rolę w rozpropagowaniu tego typu nastaw odegrały realizacje Matthiasa Steinla i lubiąskiego warsztatu (np. ołtarz kredensowy wykonany dla kościoła klasztornego w Lubiążu w latach 80. lub 90. XVII wieku ${ }^{41}$, czy ołtarz z kościoła w Krzydlinie Małej z lat 80. XVII wieku ${ }^{42}$ ). Gode, prawdopodobnie pracujący dla Lubiąża (jego dziełem mogła być zachowana fragmentarycznie fontanna do ogrodów klasztornych z około 1700 roku $^{43}$ ), zapewne znał dokonania przyklasztornego atelier. Wrocławiu Sulpiciusa Godego o kolejną dekade, z 1712 do przynajmniej 1721 roku. W księdze chrztów parafii św. Macieja w latach 1699-1721 (AAWr., księga metrykalna, sygn. 693a) artysta wzmiankowany jest kilkukrotnie, m.in. jako ojciec chrzestny: 30 października 1716 roku, 21 stycznia 1718 roku i 30 kwietnia 1721 roku. Co intrygujące, w owych trzech przypadkach brak jest określenia zawodu pomimo, że wszystkie wcześniejsze zapisy zawierały tę informację. Być może więc w połowie drugiej dekady XVIII wieku Gode wycofał się z czynnego wykonywania rzemiosła. WITKOWSKI 2016, s. 210. KOLBIARZ 2017, s. 165. HAMPREL/AQUILAS 1999, passim. KOZIEŁ 2010, passim 
Równolegle sam akant popularyzowany był przez północnowłoskich sztukatorów działających $\mathrm{w}$ regionie, a także grafiki ( $\mathrm{w}$ tym serię rycin ornamentalnych, zaprojektowanych przez Matthiasa Steinla we Wrocławiu w $1684 \mathrm{roku}^{44}$ ) oraz nowe opracowania wzorników warsztatowych. Dzięki tym wszystkim okolicznościom od przełomu lat 70. i 80. XVII wieku dekoracja roślinna zaczęła wypierać ornamentykę małżowinowo-chrząstkową, pojawiając się między innymi w zdobieniu ram obrazów i epitafiów, których kształt również mógł mieć wpływ na formę wrocławskiego ołtarza (np. monumentalne epitafium Johanna Goetza z kościoła św. Elżbiety we Wrocławiu, wyrzeźbione po 1670 roku prawdopodobnie przez warsztat Rohnów: Samuela i Paula młodszego).

Ołtarz wymurowany przez Sulpiciusa Godego należy do prekursorskich na Śląsku w kontekście retabulów ramowych. Pozbawiony jest jednak - bardzo często stosowanego w takich nastawach - motywu aniołów lecących i podtrzymujących ramę obrazu, który na Śląsku popularność zdobywał właśnie około 1700 roku. Wywodzący się ze sztuki Gianlorenzo Berniniego (w tej redakcji - z aniołami lecącymi, nie zaś stojącymi - szczególnie ważne były ołtarze ustawione około 1661 roku w kościele S. Tommaso da Vilanova w Castel Gandolfo), pojawił się na Śląsku po raz pierwszy w omówionym retabulum nyskim, ale bez bezpośrednich repetycji. Motyw ten natomiast nieco później propagowany był w kręgu mecenatu opactw cysterskich w Lubiążu, Henrykowie i Kamieńcu Ząbkowickim.

W Lubiążu pozostawiony przez Steinla w latach 80. XVII wieku przyklasztorny warsztat, po reorganizacji i pod kierownictwem nowego mistrza, prowadził w regionie ożywioną działalność przez pierwsze cztery dziesięciolecia XVIII wieku. W pierwszej dekadzie XVIII wieku zrealizował m.in. ołtarze boczne w Kaplicy Książęcej przy kościele opackim, które przyczyniły się do rozpowszechnienia w regionie kompozycji lecących aniołów. Zastosowana w Lubiążu koncepcja eliptycznej ramy obrazu unoszonej przez anioły, włączonej jednocześnie w architekturę retabulum, budzi pewne skojarzenia z rozwiązaniami wykorzystanymi w szeregu ołtarzy zaprojektowanych przez Steinla na przełomie XVII i XVIII wieku: św. Sebastiana w wiedeńskim kościele Franciszkanów (1696), głównym i kredensowym w Vorau (1701-1704) i Ukrzyżowania w kościele parafialnym w Krems (1706-1708) ${ }^{45}$. Kwestią otwartą pozostaje, czy wykonawca lubiąskich nastaw znał dzieła Steinla z autopsji, czy ewentualnie sam Austriak mógł mieć udział w projektowaniu ołtarzy z lubiąskiej kaplicy ${ }^{46}$.

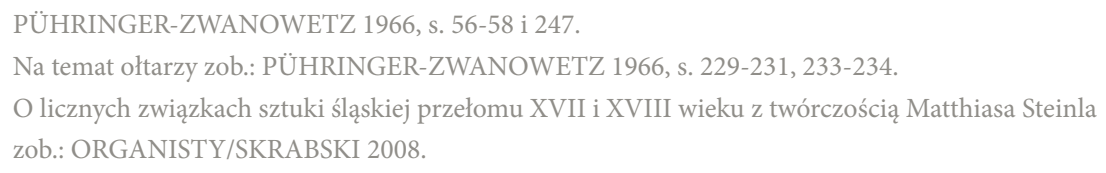




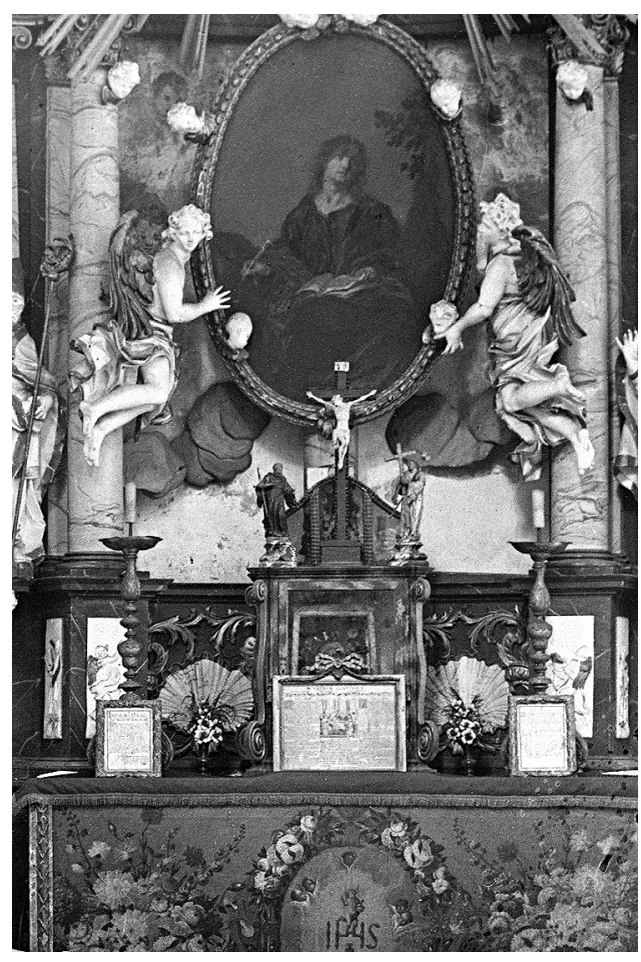

Lubiąski warsztat,

ottarz św. Jana Ewangelisty na Patmos, Kaplica Książęca, Lubiąż. 1. dekada XVIII wieku. Stan sprzed 1945 roku.

Fot. Bildarchiv Marburg, sygn. fm95057a

Atrybucja wspomnianego zespołu ołtarzy jest zagadnieniem złożonym, lecz istotnym przez wzgląd na znaczenie tych dzieł dla rozwoju śląskiej plastyki późnobarokowej ${ }^{47}$. Na obecnym stanie badań nie jest on kojarzony z warsztatem przyklasztornym, lecz z artystami zewnętrznymi ${ }^{48}$, którzy mieli czasowo podjąć się prac dla Lubiąża. Wystrój figuralny tych nastaw nie jest jednak dziełem odosobnionym pod względem stylowym. Analogie znajdują się (bądź znajdowały do zniszczenia około 1945 roku) zarówno w samym Lubiążu (np. rzeźby elewacji Kaplicy Loretańskiej z 1. dekady XVIII wieku ${ }^{49}$, jak i w okolicy (m.in. kamienne figury św. Jana Nepomucena

Nowatorska - czasem określana, jako protorokokowa - stylistyka jaką operował warsztat (wspominany w publikacjach przede wszystkim w kontekście dekoracji Kaplicy Loretańskiej w Lubiażu) zwrócił uwagę badaczy, którzy wprowadzili do literatury błędną atrybucję, niestety obecną także w syntetycznym opracowaniu sztuki w Polsce. Por.: SITO 2016, s. 382.

48 W starszej literaturze takie przekonanie wyraziła Małgorzata Żydowicz (ŻYDOWICZ 1986, s. 155). Podobną opinię wygłosił Bogusław Czechowicz (CZECHOWICZ 1993, s. 266-268), by w późniejszej publikacji przyznać atrybucję Antonowi Kuenowi, wysuniętą przez Konstantego Kalinowskiego (CZECHOWICZ 2012, s. 14).

49 Ten sam warsztat wykonał również dekoracje portalu klasztoru (1706) i kościoła klasztornego (około 1710-1715), figury zdobiące bramę wjazdową do opactwa (początek XVIII wieku), a także wystrój ołtarzy św. Anny i Matki Boskiej Dobrej Rady (około 1728) w obejściu świątyni, anioły wtórnie włączone do wystroju prospektu organowego oraz figury z baldachimu tronu opata tamże (1. tercja XVIII wieku). Por.: KOLBIARZ 2010A, s. 470; CZECHOWICZ 2012, s. 15. 
przed ratuszem w Wołowie z 1723 roku i kościołem w Stobnie z 1731 roku $)^{50}$. Liczebność zabytków, ograniczony zasięg terytorialny ich występowania oraz znaczna rozpiętość czasowa wskazują, że jest to efekt działalności miejscowego - lubiąskiego warsztatu. Tymczasem w literaturze ołtarze boczne z Kaplicy Książęcej przypisywane są Johannowi Christophowi Königowi ${ }^{51}$. Dekoracje elewacji Kaplicy Loretańskiej natomiast łączone są z Franzem Antonem Kuenem - austriackim rzeźbiarzem czynnym w Czechach w latach 1713-1719, który wedle postawionej hipotezy wcześniej miałby pracować dla Lubiąża ${ }^{52}$. Żadna z zaproponowanych kandydatur nie znajduje jednak potwierdzenia $w$ analizie formalnej lubiąskich dzieł ${ }^{53}$. Przeciwko nim świadczy również fakt długotrwałego operowania przez warsztat jednorodną stylistyką (od początku XVIII wieku, aż po lata 30.). Jedynie w omawianych ołtarzach z Kaplicy Książęcej zauważalne jest pewne zróżnicowanie form. Część figur zdobiących retabula charakteryzuje bowiem bardziej masywne opracowanie draperii, bliższe kreacjom pracowni lubiąskiej z lat 80 . i 90 . XVII wieku. Sugeruje to zatrudnienie w 1. dziesięcioleciu XVIII wieku w przyklasztornym warsztacie dwóch osobowości artystycznych, dysponujących nieco odmiennym wykształceniem zawodowym."

Zaginięcie ksiąg metrykalnych Lubiąża z przełomu XVII i XVIII wieku utrudnia wiążącą dyskusję w kwestii autorstwa omawianych nastaw. Szczęśliwy zbieg 
okoliczności pozwala jednak wskazać artystę współtworzącego przyklasztorne atelier w 1. dekadzie XVIII wieku. 7 czerwca 1706 roku we wrocławskim kościele św. Macieja ślub brał Michael Gabriel Raphael Lichtner, określony przy tej okazji jako „Bildhauer bei Closteri Leubus” ${ }^{4}$. Czy był on rzeźbiarzem prowadzącym wówczas cały warsztat, tego na dzień dzisiejszy nie możemy jednoznacznie rozstrzygnąć. $\mathrm{Z}$ całą pewnością był jednak artystą z tytułem mistrzowskim, a więc jeśli nie jedynym, to jednym $z$ dwóch, góra trzech rzeźbiarzy o takim statucie, jacy mogli współtworzyć pracownię̧ $e^{55}$ Być może to właśnie on odpowiadał za niektóre, wyróżniające się stylem rzeźby z ołtarzy bocznych Kaplicy Książęcej. Działalność Lichtnera w Lubiążu nie trwała bowiem długo. Od 1710 roku artysta notowany był już w księgach metrykalnych wrocławskiej parafii przy kościele NMP na Piasku. Zamieszkiwał w tamtejszych dobrach klarysek do swojej śmierci 13 sierpnia 1716 roku, w wieku 34 lat $^{56}$. Natomiast po odejściu Lichtnera z Lubiąża na służbie cystersów pozostał nieznany z nazwiska artysta, posługujący się bardziej ekspresyjną formułą stylową. Prowadził on z powodzeniem warsztat przez trzy kolejne dekady, także przyczyniając się do rozwoju retabulów atektonicznych (ołtarze św. Anny i Matki Boskiej Dobrej Rady z kościoła opackiego w Lubiążu, wykonane około 1728 roku).

Poza Lubiążem wczesną recepcję na Śląsku motywu figur anielskich towarzyszących obrazom stanowią bogate ramy malowideł dekorujących skrzyżowania naw kościołów cysterskich w Henrykowie (pierwsza dekada XVIII wieku ${ }^{57}$ ) i Kamieńcu Ząbkowickim (Leopold Strauss - 1713) ${ }^{58}$. Możliwe, że w kwestii kształtu i sposobu rozbudowania zdobień akantowych dla tych dzieł inspirację stanowiły ramowe ołtarze w transepcie kościoła Krzyżowców z Czerwoną Gwiazdą na Starym Mieście w Pradze, wyrzeźbione przez Matthäusa Wenzela Jäckla w 1701 i 1702 roku $^{59}$. Mieszczą one obrazy Johanna Christopha Liški, który - co jest istotną okolicznością - namalował później całą serię obrazów do Henrykowa i Kamieńca Ząbkowickiego.

Wkrótce potem, przy okazji wzniesienia retabulum dla kościoła pielgrzymkowego w Bardzie, zastosowany został pełny program anielskiego ołtarza ramowego-akantowego (dodatkowo z baldachimem). W tym przypadku możemy już mówić

\footnotetext{
54 AAWr., księga metrykalna, sygn. 693a, s. 45.

55 Na temat sposobów organizacji warsztatów rzeźbiarskich w epoce baroku, zob.: WITTKOWER 1974, passim; TRATZ 1988, passim; KALINOWSKI 1995, passim. Zob. AAWr., księgi metrykalne, sygn. 442b i $442 \mathrm{~m}$.

57 Podwójny herb połączonych unią personalną opactw w Henrykowie i w Zirc datuje czas wykonania ram po 1699 roku, niezależnie od toczącej się w literaturze dyskusji odnośnie autorstwa i datowania samych obrazów (na ten temat, zob.: KOZIEŁ 2013, s. 212-213). 
Leopold Strauss, ołtarz główny, kościół Nawiedzenia NMP, Bardo, 1714-1715 i 1720-1721,

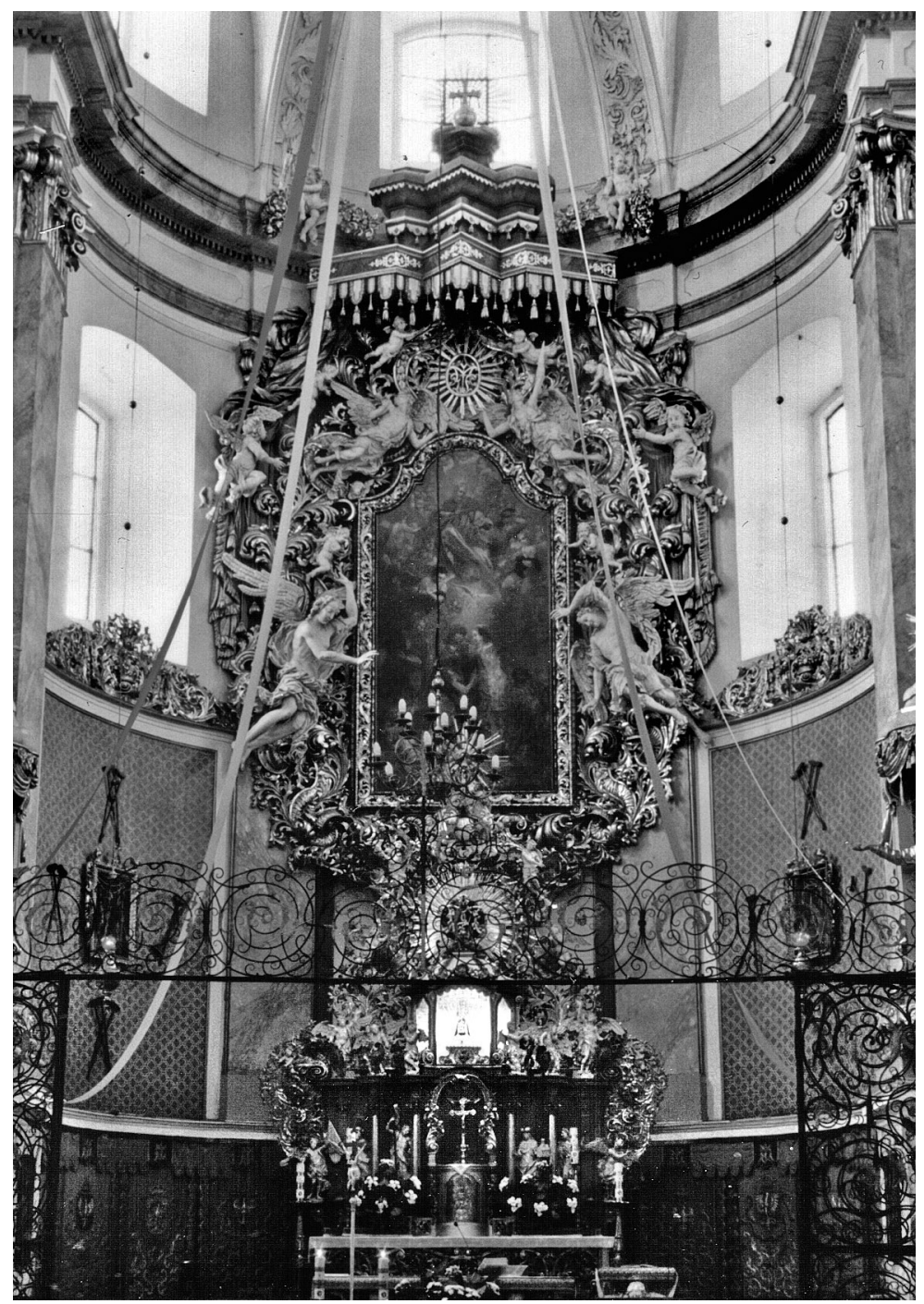

fot. Artur Kolbiarz, 2010

o ogólnej inspiracji starszym o niemal pół wieku ołtarzem z kościoła św. Jakuba w Nysie. Nie było to jednak naśladownictwo ze względu na zdecydowanie bardziej wyeksponowaną rolę obramienia akantowego w nastawie z Barda. Wskazuje to, podobnie jak we wspomnianych ramach obrazów z Henrykowa i Kamieńca Ząbkowickiego, na odwoływanie się do wciąż jeszcze wtedy aktualnej tradycji Akanthusaltare.

Na temat bardzkiego retabulum narosło wiele nieporozumień dotyczących okoliczności jego powstania. Przez lata powtarzane były błędne informacje o wystawieniu dzieła przez wrocławskiego stolarza Nicolasa Richtera ${ }^{60}$. Przekazy archiwalne

60 SCHWETER 1922, s. 288; SCHWETER 1939, s. 8; CHRZANOWSKI 1980, s. 71; CHRZANOWSKI 1981, s. 90-92; KALINOWSKI 1986, s. 199-200; SCHWETER 2001, s. 156; DEHIO 2006, s. 98 , ORGANISTY/SKRABSKI 2008, s. 200. 
jednoznacznie określają go jednak wyłącznie jako wykonawcę drewnianych fragmentów niezachowanego, srebrnego tabernakulum autorstwa wrocławskiego złotnika Tobiasa Plakwitza z lat 1716-1717. Natomiast istniejący ołtarz wyszedł spod dłuta ząbkowickiego artysty: Leopolda Straussa, który w latach 1714-1715 wykonał bogato zdobioną ramę, a w latach 1720-1721 (ze względu na konieczność usunięcia dzieła Plakwitza) został zatrudniony przy nowym, tym razem drewnianym tabernakulum $\mathrm{z}$ tronem dla figury maryjnej ${ }^{61}$.

Bardzki ołtarz zawiera motyw rozchylonej kotary, ujmującej po bokach nasta$w_{e} e^{62}$. Jednakże wyraźnie odmienny styl rzeźb putt podtrzymujących poły materiału sugeruje współpracę z anonimowym rzeźbiarzem, ewentualnie dodanie - razem $\mathrm{z}$ baldachimem koronującym ołtarz - tych elementów nieco później (ale przed 1738 rokiem, z którego pochodzi grafika, ukazująca w uproszczonej formie istniejącą aranżację). W zależności od przyjętej wersji datowania nastawa bardzka mogła stanowić inspirację albo recepcję środkowej części ołtarza w kościele pojezuickim w Kłodzku, zaprojektowanego około 1728 roku przez Christopha Tauscha ${ }^{63}$.

Leopold Strauss z powodzeniem stosował koncepcję ołtarza ramowego w dalszych realizacjach: nastawach z kościoła w Wadochowicach (2. lub 3. dekada XVIII

\footnotetext{
61 KOLBIARZ 2011A, s. 188-119; KOLBIARZ 2011B, s. 92-95.

62 Józef Skrabski i Adam Organisty wskazują dzieła Matthiasa Steinla jako możliwe źródło inspiracji dla motywu kotary. Zob.: ORGANISTY/SKRABSKI 2008, s. 201.

63 Na temat obiektu zob.: GALEWSKI 2012, s. 147-153. Tamże starsza literatura.
}

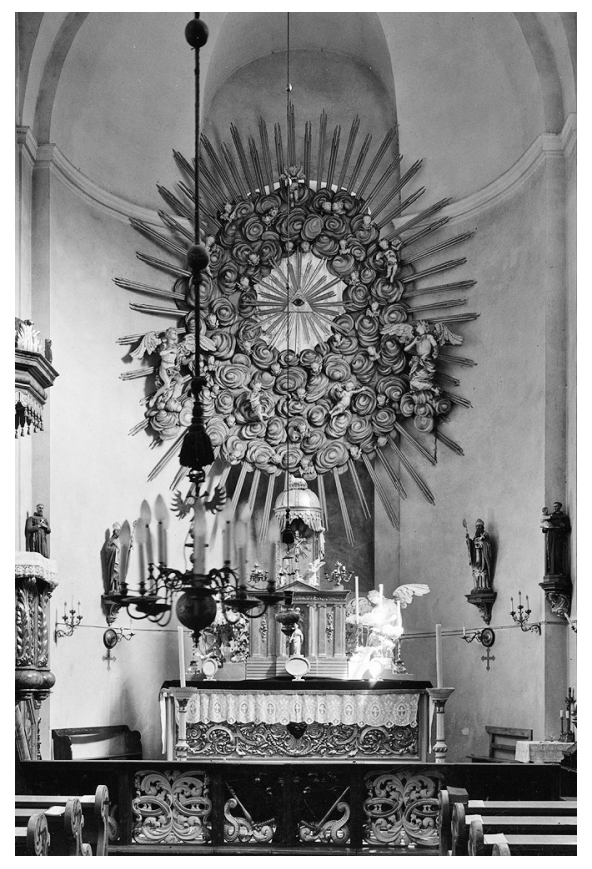

Leopold Strauss (atryb.), ołtarz główny, kaplica zamkowa, Karłowice, po 1715. Stan sprzed 1945 roku. Fot. Instytut Sztuki PAN, sygn. 234209 
wieku $^{64}$ ) oraz kaplicy pałacowej w Łagiewnikach (2. lub 3. dekada XVIII wieku ${ }^{65}$ ). $\mathrm{W}$ obu przypadkach fundatorami byli henrykowscy mnisi. Poza ich mecenatem Strauss wykonał natomiast ciekawą nastawę do kaplicy zamkowej w Karłowicach (po $1715 \mathrm{roku}^{66}$ ), ukazującą jak bliskie było artyście dążenie do dematerializacji architektury ołtarzowej, rozwiązywanej na różne sposoby. Karłowicki ołtarz w typie ramowym-ornamentalnym, dzięki wyeksponowanemu motywowi otoku $\mathrm{z}$ chmur ujmującemu okno w prezbiterium, stanowił dalekie echo słynnego, Cathedra Petri Berniniego z watykańskiej bazyliki ${ }^{67}$.

Ołtarz główny w Bardzie rozpoczął ewolucję nastaw ramowych w dominium cystersów henrykowskich i kamienieckich. Nie oznaczało to jednak powtarzania jego kształtu, lecz wznoszenie różnych wariantów retabulum o wyraźnie oddzielonej ramie od mensy. Ten krótkotrwały etap poszukiwań zakończył się na przełomie lat 30. i 40. XVIII wieku, kiedy pod wpływem sztuki krajów habsburskich na Śląsku zakorzeniły się nowe wzorce ołtarzy tego typu, wpływając przy okazji na większą unifikację form.

Dobrym przykładem wczesnego retabulum ramowego jest ołtarz w Mąkolnie, dawnym kościele patronackim Kamieńca Ząbkowickiego. Wzniesiony wkrótce po ukończeniu świątyni w 1722 roku $^{68}$, łączy elementy atektoniczne (obłoki) z architektonicznymi (masywne gzymsy pod i nad obrazem), które jednak nie posiadają funkcji tektonicznej. Na podstawie analizy porównawczej jego wykonanie łączyć należy z Antonem Jörgiem, działającym w pobliskim Kamieńcu Ząbkowickim ${ }^{69}$ od około $1720^{70}$ do przynajmniej 1736 roku, a potem w Nysie (gdzie był rzeźbiarzem

\footnotetext{
64 Dzieło zostało mocno przekształcone w XIX wieku. Dodano wtedy bramki oraz architektoniczne ujęcie obrazu i zwieńczenie.

$65 \quad Z$ oryginalnego obiektu zachowane są jedynie cztery figury anielskie, włączone do późniejszej aranżacji.

66 Katalog zabytków 1961A, s. 41.

67 Niestety, przy okazji przeniesienia obiektu z kaplicy zamkowej do miejscowego kościoła ołtarz dostosowano do nowego wnętrza, integrując otok z obłoków z tabernakulum i zaślepiając otwór w centrum retabulum.

68 W 1784 roku (data na kartuszu pod obrazem) ołtarz rozbudowano, dodając po bokach mensy bramki z figurami śś. Benedykta i Bernarda.

69 Na temat życia artysty i funkcjonujących w literaturze nieścisłości, zob.: KOLBIARZ 2010B, s. 156.

70 Najwcześniejszy zapis archiwalny informujący o obecności Jörga w Kamieńcu pochodzi z 28 marca 1721 roku (zob.: AAWr. księga metrykalna, sygn. 127a, s. 248), ale nieco wcześniej powstały najwcześniejsze znane dzieła artysty: figury śś. Jana Nepomucena i Floriana, zdobiące most przy wjeździe do opactwa. Na cokole tej ostatniej rzeźby znajdują się inicjały fundatora: opata Gerarda Woiwody (G.A.C.), ujmujące monogram informujący o roku ustawienia figur, utworzony z nałożonych na siebie cyfr: 0127. Należy je odczytać jako 1720, bowiem druga możliwa konfiguracja - 1702 - oznaczałaby zbyt wczesne datowanie. Jörga w tym czasie z całą pewnością nie było jeszcze w Kamieńcu Ząbkowickim.
} 

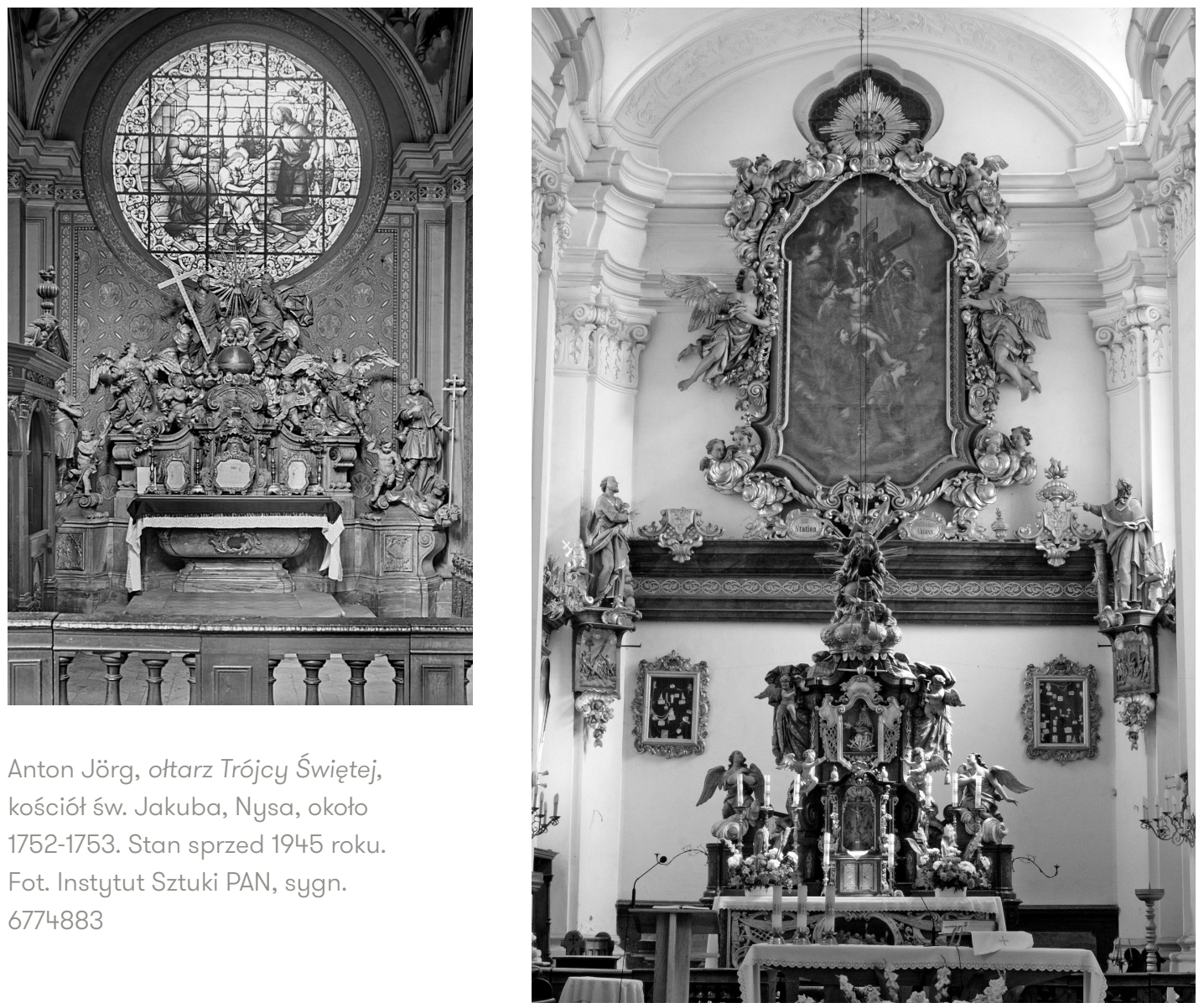

Anton Jörg, ołtarz Trójcy Świętej, kościół św. Jakuba, Nysa, około 1752-1753. Stan sprzed 1945 roku. Fot. Instytut Sztuki PAN, sygn. 6774883

w służbie biskupów wrocławskich ${ }^{71}$ ) do śmierci pod koniec 1758 roku. Obecny stan badań nad życiem artysty, pełen nieścisłości i chybionych hipotez, sytuuje go na marginesie badań nad barokową rzeźbą śląską ${ }^{72}$. Tymczasem Jörg należał do najlepiej wykształconych rzeźbiarzy w regionie i odpowiadał za szereg wybitnych realizacji. Jedną z nich jest ołtarz Trójcy Świętej ${ }^{73}$, wykonany prawdopodobnie w latach

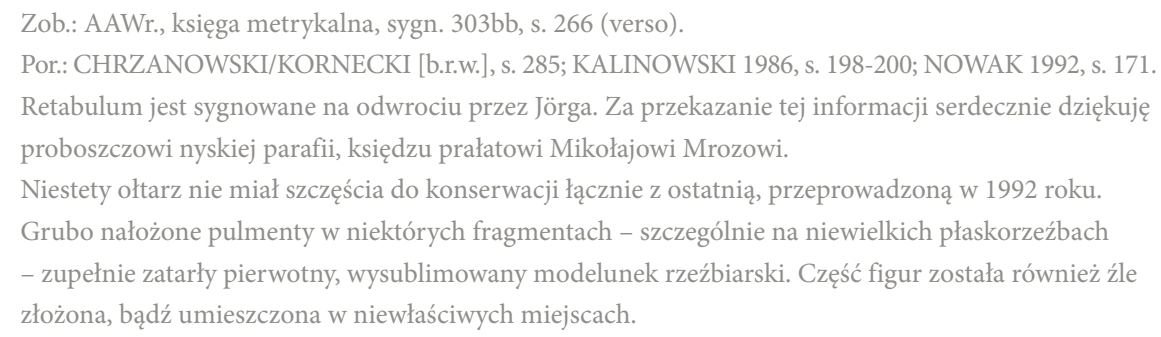

Anton Jörg, Andreas Ludwig Jäschke, Johann Nepomucen Hartmann (atryb.), ołtarz główny, kościół Matki Boskiej Bolesnej, Bobolice, około 1743, 1759 i około 1780, fot. Artur Kolbiarz, 2013 
1752-1753 dla kościoła św. Jakuba w Nysie ${ }^{74}$, prezentujący niezbyt często spotykaną na Śląsku odmianę retabulum - ołtarz tabernakulowy ${ }^{75}$.

Jörg, pracując przez długi czas w Kamieńcu Ząbkowickim, wywarł istotny wpływ na artystów bardzkich, chociażby Andreasa Ludwiga Jäschkego. Istnieje nawet wspólna realizacja obu artystów - wykonany w kilku etapach ołtarz główny kościoła pielgrzymkowego w Bobolicach. Najpierw Anton Jörg wystawił retabulum tabernakulowe $\mathrm{z}$ tronem dla słynącej łaskami figury gotyckiej. Miało to prawdopodobnie miejsce około 1743 roku, z którego pochodzi obraz ołtarzowy Felixa Antona Schefflera $^{76}$. Potem, w 1759 roku $^{77}$, malowidło Schefflera uzyskało nową ramę wykonaną w warsztacie Jäschkego. Około 1780 roku ostatecznie aranżację nastawy uzupełniły figury ustawione w narożach prezbiterium, zrealizowane najprawdopodobniej przez Johanna Nepomucena Hartmanna. Jäschke podobny schemat nastawy zastosował jeszcze w kościele św. Jadwigi Śląskiej w Ząbkowicach Śląskich (około 1756 roku).

Retabula z Bobolic i Ząbkowic Śląskich stanowią doskonałą egzemplifikację schematu ramowej nastawy, obowiązującego w bardzkim ośrodku artystycznym około połowy XVIII wieku. Ewolucja form doprowadziła do redukcji elementów i wysmuklenia proporcji. Jednocześnie nastąpiła większa standaryzacja kompozycji nastaw. Zmiany te następowały równolegle do ewolucji sztuki w dużych ośrodkach artystycznych na Śląsku. Dla przykładu we Wrocławiu podobnymi formami operował Franz Joseph Mangoldt - m.in. w ołtarzach na ścianach bocznych prezbiterium świątyni cysterek w Trzebnicy z około 1745 roku i nastawach w transepcie kościoła św. Krzyża we Wrocławiu z około $1750 \mathrm{roku}^{78}$. W tym czasie pośród możliwych

Datowanie ołtarza nie zostało precyzyjnie ustalone. Większość badaczy przyjmuje jego powstanie na czas wzniesienia samej kapicy lub bezpośrednio po. Zob.: Katalog zabytków 1963, s. 85; KĘBŁOWSKI 1972, s. 67-69; CHRZANOWSKI/KORNECKI [b.r.w.], s. 304; KALINOWSKI 1986, s. 245. Henryk Dziurla - powołując się na podobieństwa z realizacjami Chrisophora Tauscha - niesłusznie forsował hipotezę o zaprojektowaniu ołtarza przez jezuitę i wykonaniu przez warsztat Johanna Albrechta Siegwitza jeszcze w 1. połowie XVIII wieku. Jego zdaniem ołtarz został wtórnie umieszczony w kościele św. Jakuba i miał pochodzić z rozebranej kaplicy szpitalnej pod wezwaniem św. Trójcy. Por.: DZIURLA 1991, s. 182-184. Tymczasem sygnatura oraz stylistyka dzieł niezbicie wskazują na autorstwo Jörga. Również detale architektoniczne ołtarza należą do obiegowych w twórczości nyskiego rzeźbiarza (widocznych choćby w sygnowanych monumentach z Bystrzycy Kłodzkiej i Głubczyc). Podobieństwa do dzieł Tauscha wynikają zarówno z ewidentnej znajomości prac jezuickiego architekta, malarza i wynalazcy, jak i ze wspólnego dla obu artystów, a niezwykle popularnego w Europie Środkowej wzorca - twórczości Andrei Pozza. Por.: SCHEMPER-SPARHOLZ 1998, s. 53-54. HETTWER 1937, s. 26; ORGANIŚCIAK/DUDZIAK/DZIEDZIC 1997, s. 65; DEHIO 2006, s. 126. Datowanie wynika z chronostychu umieszczonego na tarczach trzymanych przez putta: „AspICe Do Lentes Vero” i „passIoneM ChrIstI”.

78 Datowanie za: Die Kunstdenkmäler 1930, s. 194. 
inspiracji dla śląskich ołtarzy ramowych wspomnieć wypada dokonania artystów austriackich, ze szczególnym wskazaniem Johanna Lucasa von Hildebrandta. Jego wzorcowe retabula z kościoła parafialnego w Pottendorf z lat 1717-1718 ${ }^{79}$, czy kaplicy Górnego Belwederu w Wiedniu z około 1720 roku $^{80}$, zdobyły szybko popularność. Co ciekawe, prace te kształtem nie odbiegają daleko od znacznie starszego, omówionego wcześniej retabulum z Nysy.

Charakterystyczne dla wielu ołtarzy powstających w XVIII wieku było rozbudowywanie strefy cokołowej poprzez dodawanie bramek ujmujących mensę. Element ten widoczny jest także w dziełach artystów bardzkich. Warsztat Andreasa Ludwiga Jäschkego lub anonimowy współpracownik (niesłusznie utożsamiany z Josephem Michaelem Steinerem ${ }^{81}$, który był malarzem) zrealizował taką nastawę w świątyni pocysterskiej w Laskówce (3. ćwierć XVIII wieku). Z lat 80. XVIII wieku pochodzi wyrzeźbiony przez Jäschkego ołtarz w Wojborzu i jako późne dzieło zawiera już

Datowanie za: KERN 2011, s. 93.

Na temat obiektu, zob.: DEHIO 1993, s. 83.

Por.: CHRZANOWSKI 1981, s. 93.

Franz Joseph Mangoldt,

ottarz boczny,

kościół Świętego Krzyża,

Wrocław, około 1750.

Stan sprzed 1945 roku.

Fot. Instytut Sztuki PAN,

sygn. 240488

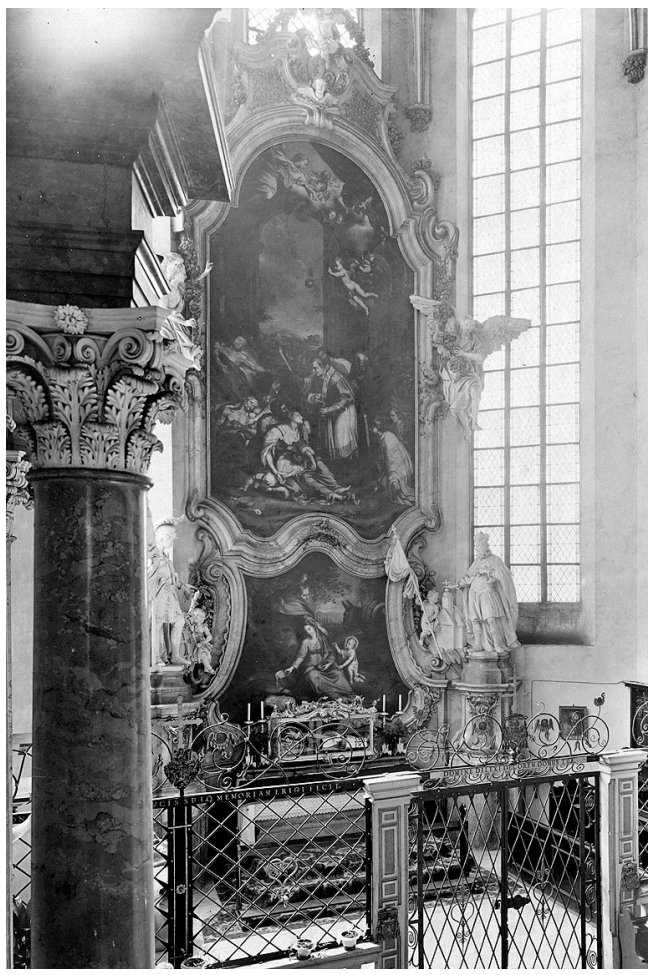




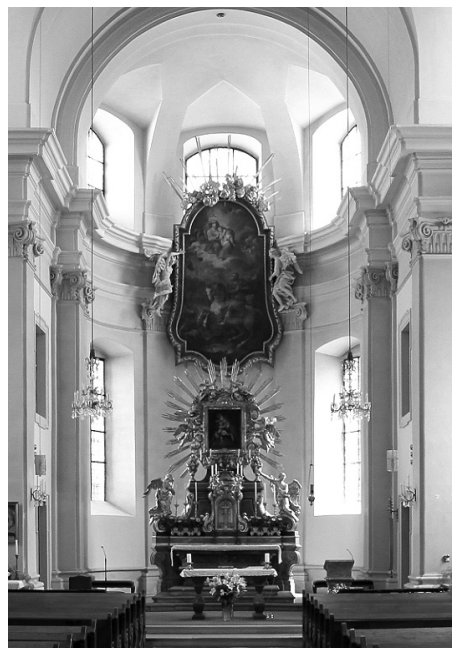

Johann Lucas von Hildebrandt, ołtarz główny, kościół św. Jakuba, Pottendorf, 1717-1718. Fot. ze zbiorów autora.

Joseph Hartmann (atryb.), ottarz główny, kościół św. Dominika, Nysa, około 1787, fot. autor (2014) elementy zdobnictwa zopffowego. W wyjątkowych przypadkach dolne części ołtarzy zyskiwały monumentalny, parawanowy charakter, jak w nastawie z kościoła podominikańskiego w Nysie (około 1787 roku). Jej domniemany autor Joseph Hartmann (ewentualnie jego naśladowca), po ukończeniu nauk u ojca przeniósł się około 1772 roku z Barda do Nysy. Pracował tam aż do śmierci 20 listopada 1787 roku $^{82}$, a jego działalność zdominowała rokokową rzeźbę księstwa biskupiego. Joseph sięgał jeszcze kilkukrotnie po schemat ołtarza ramowego (retabulum z kościoła w Przełęku), przyczyniając się do ugruntowania jego popularności w nyskim księstwie biskupim i w jego sąsiedztwie.

Oczywiście rzeźbiarze bardzcy nie posiadali w regionie monopolu na ołtarze ramowe i obok nich ważne realizacje firmowane były przez konkurencyjne warsztaty. Dla przykładu kościół w Krzelkowie zdobi nastawa przeniesiona ze świątyni klasztoru Krzyżowców z Czerwoną Gwiazdą w Ziębicach. Akantowo-wolutowy ołtarz z bramkami wykonany został stosunkowo wcześnie, bo około 1730 roku

82 AAWr. księga metrykalan sygn. $303 e e$, s. 335 (verso).

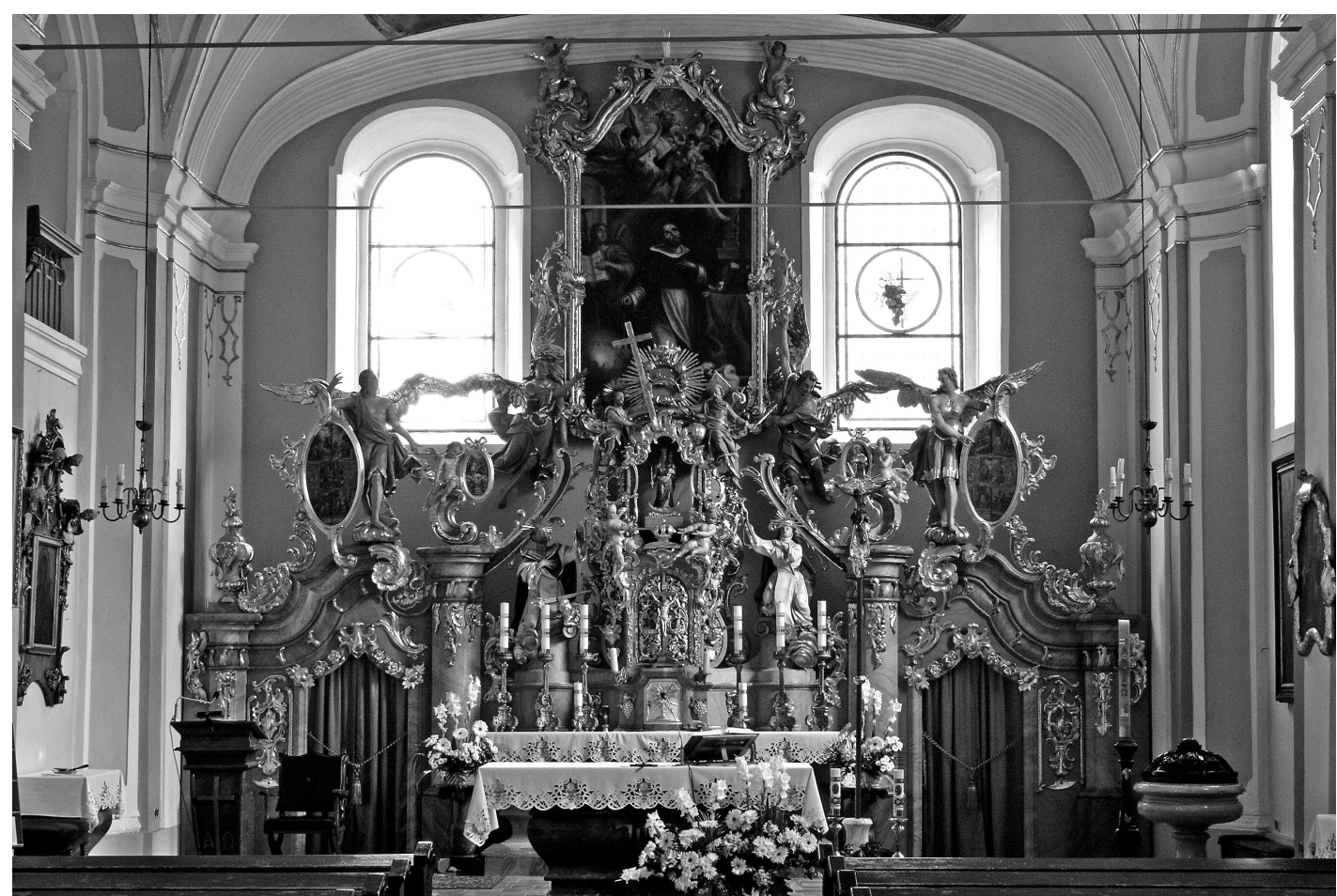


najprawdopodobniej przez Georga Schencka ${ }^{83}$, artystę działającego w Ziębicach, a potem Nysie. Z lat 50. XVIII wieku pochodzi natomiast ołtarz główny kościoła w Lubnowie wykonany przez epigona Michaela Klahra Starszego. Mógł nim być Johann Joseph Prausse, czynny w połowie stulecia w Lądku Zdroju, z którym łączony jest ołtarz ramowy w pobliskich Chałupkach ${ }^{84}$. Dla Henrykowa - w którym tradycja ołtarzy atektonicznych (głównie akantowych) była silnie zakorzeniona - przez krótki czas pracował Leopold Jäschke, osiadły na Wyspie Piaskowej we Wrocławiu i być może spokrewniony z bardzkim Andreasem Ludwigiem. Jego dziełem jest ołtarz wolutowo-ramowy w kaplicy św. Marii Magdaleny przy kościele klasztornym $(1760)^{85}$. Dzieła te, choć nie jedyne, uzupełniają przegląd ołtarzy ramowych w księstwie ziębickim i nyskim.

Reasumując, ewolucja ołtarzy ramowych na Śląsku, w tym w środowisku artystycznym Barda, przebiegała podobnie do rozwoju sztuki pozostałych krajów habsburskich. Wyjątek stanowi ołtarz z kościoła św. Jakuba w Nysie, swoją formą wyprzedzający znane analogie w krajach zaalpejskich, ale który - co zastanawiające - nie był naśladowany bezpośrednio po wzniesieniu. Śląskie ołtarze ramowe w większej ilości zaczęły się pojawiać po 1700 roku, łącząc doświadczenia sztuki zaalpejskiej (retabula i epitafia akantowe) z teatralizującymi motywami zaczerpniętymi z Italii (anioły unoszące obraz). Wygląd ołtarzy był początkowo dość zróżnicowany i zależał od indywidualnych koncepcji autorów. W księstwie

\footnotetext{
83 Datowanie za: WOJTYŁA 2012, s. 317. W literaturze ołtarz wiązany jest z działającym w Czechach Ignazem Rohrbachem lub z jego kręgiem (por.: ORGANISTY 2007, s. 243-244). Tymczasem putta na krzelkowskim ołtarzu są niemal identyczne z aniołkami pochodzącymi z ambony przypisywanej Schenckowi, należącej pierwotnie do wystroju kościoła Krzyżowców w Ziębicach, a przechowywanymi w Muzeum Narodowym we Wrocławiu (por.: NOWAK 1994, s. 127-128). Figury śś. Piotra i Pawła ustawione na bramkach wykazują wyraźne pokrewieństwa z kamiennymi rzeźbami portalu kościoła Bożogrobców w Nysie, powiązanych przekonująco z Schenckiem przez Ewę Grochowską-Sachs. Dodatkowo opracowanie głów z przerysowaniem detalu analogiczne jest do figur alegorycznych z ogrodów zamku Książ, sygnowanych przez tego artystę. Por.: GROCHOWSKA 2012, s. 289-290. Z Schenckiem wiązać należy również parę ołtarzy bocznych w kościele w Przełęku (również kojarzonych dotąd z kręgiem Rohrbacha. Por.: ORGANISTY 2007, s. 244), które być może także pierwotnie należały do wyposażenia kościoła klasztornego w Ziębicach (jeden z nich na belkowaniu posiada herb zakonu), rozdysponowanego po sekularyzacji do okolicznych świątyń. Wspólne pochodzenie wymienionych zabytków, a przynajmniej wspólny mecenat, dodatkowo wzmacnia hipotezę atrybucyjną.

84 Artysta w 1747 roku wykonał projekt dolnej części ołtarza z tabernakulum i figurą św. Jana Nepomucena złożonego w grobie. GROCHOWSKA-SACHS 1999, s. 12; CZECHOWICZ 2001, s. 60.

85 Obaj rzeźbiarze bywają ze sobą myleni. Por.: KALINOWSKI 1986, s. 248. Sprawę rozstrzygają archiwalia jasno mówiące, że to Ludwig wykonał ołtarz św. Marii Magdaleny. Zob.: AAWr. Sygn. VB6s. Analiza stylistyczna w pełni potwierdza zapisy źródłowe.
} 
ziębickim nastawy ramowe obecne były już w twórczości artystów bezpośrednio poprzedzających rozkwit ośrodka bardzkiego: Leopolda Straussa, Antona Jörga i Georga Schencka. Po ich śmierci lub migracji rolę przewodnią w regionie przejęli pracujący w Bardzie Andreas Ludwig Jäschke i Johann Heinrich Hartmann, którzy posługiwali się już formami ołtarzy w redakcji zainspirowanej sztuką Arcyksięstwa Austriackiego 1. połowy XVIII wieku (przede wszystkim dziełami Johanna Lucasa von Hildebrandta i Antonia Beduzziego). Ramowy typ nastawy wykorzystywany był aż do końca działalności ośrodka, na przełomie XVIII i XIX wieku. Intensywna działalność o szerokim zasięgu terytorialnym sprawiła, że twórczość bardzkich artystów wywarła istotny wpływ na rzeźbę i małą architekturę południowo-wschodniej części Dolnego Śląska.

W produkcji ośrodka artystycznego w Bardzie ołtarze ramowe były licznie reprezentowane, ale nie stanowiły większości. Aediculowe, architektoniczne retabula zdecydowanie dominowały na rynku zleceń. Tym niemniej wypada zgodzić się z obserwacjami Tadeusza Chrzanowskiego, który zauważył zwiększoną popularność nastaw ramowych w okolicach Kamieńca Ząbkowickiego w porównaniu z innymi obszarami Śląska. Zaryzykować można stwierdzenie, że mogło to wynikać z wysokiej rangi ołtarza w Bardzie, stanowiącego oprawę dla cudownej figury Matki Boskiej. Jej kult propagowany był głównie przez kamienieckich oraz henrykowskich cystersów i to właśnie w ramach mecenatu tego zakonu powstało najwięcej ołtarzy ramowych. 


\section{Bibliografia:}

- CHRZANOWSKI 1980 - Tadeusz Chrzanowski, Bardo, (w serii: Śląsk w zabytkach sztuki), Wrocław - Warszawa - Kraków 1980.

- CHRZANOWSKI 1981 - T. Chrzanowski, Die Schlesische Barockskulptur um 1700 - Durchbruch oder Stabilisierung?, [w:] Barockskulptur in Mittel-und Osteuropa, hrs. K. Kalinowski, Poznań 1981, s. 81-102.

- CHRZANOWSKI/KORNECKI [b.r.w.] - Tadeusz Chrzanowski, Marian Kornecki, Sztuka Śląska Opolskiego. Od średniowiecza do końca XIX w., Kraków [b.r.w.].

- CZECHOWICZ 1993 - Bogusław Czechowicz, Domki loretańskie na Śląsku, „Studia Teologiczno-historyczne Śląska Opolskiego" 14 (1993), s. 253-274.

- CZECHOWICZ 2001 - Bogusław Czechowicz, Osobliwy Nepomucen. Rzeźba świętego z 1741 roku w kościele w Gorzanowie, [w:] Pielgrzymy. Informator Krajoznawczy poświęcony Sudetom, red. Tomasz Dudziak/Bożena Mrugalska/Piotr Mrugalski/Marek Furmankiewicz, Wrocław 2001, s. 54-64.

- CZECHOWICZ 2012 - Bogusław Czechowicz, Rokoko przed rokokiem? Jeszcze o wystroju rzeźbiarskim kaplicy loretańskiej w opactwie Cystersów w Lubiążu, [w:] Splendor i fantazja. Studia nad rzeźba rokokową w dawnej Rzeczypospolitej i na Śląsku, red. Paweł Migasiewicz, Warszawa 2012, s. 13-22.

- DEHIO 1993 - Dehio-Handbuch. Die Kunstdenkmaler Osterreichs, Wien II bis IX und XX Bezirk, Wien 1993.

- DEHIO 2006 - Dehio. Zabytki sztuki w Polsce. Śląsk, red. Sławomir Brzezicki/Christine Nielsen/Georg Grajewski/Dietmar Popp, Warszawa 2006.

- DEHIO 2010 - Dehio-Handbuch. Die Kunstdenkmaler Osterreichs. Niederosterreich nordlich der Donau, 2. Auflage, Wien 2010.

- Die Kunstdenkmäler 1930 - Die Kunstdenkmäler der Provinz Niederschlesien, Bd. I, Die Stadt Breslau, T. 1, hrg. Ludwig Burgemesiter, Breslau 1930.

- Die Kunstdenkmäler 1934 - Die Kunstdenkmäler der Provinz Niederschlesien, Bd. I, Die Stadt Breslau, T. 3, hrgs. Ludwig Burgemesiter, Günther Grundmann, Breslau 1934.

- DZIURLA 1991 - Henryk Dziurla, Christophorus Tausch, uczeń Andrei Pozza, (w serii: Historia Sztuki V, Acta Universitatis Vratislaviensis No 1322), Wrocław 1991.

- GROCHOWSKA 2012 - Ewa Grochowska, Dekoracja rzeźbiarska cour d’honneur zamku Książ na Śląsku. Splendor i fantazja. Studia nad rzeźbą rokokową w dawnej Rzeczypospolitej i na Śląsku, red. Paweł Migasiewicz, Warszawa 2012, s. 277-291.

- GROCHOWSKA-SACHS 1999 - Ewa Grochowska-Sachs, Nachricht aus anderen Zeiten. Fascinierender Fund aus dem ehem. Gutsarchiv Neuhaus, „Niederschlesisches Informationsblatt. Zeitschrift der Deutschen Sozial-Kulturellen Gesellschaft in Breslau“ 3 (1999), s. 12.

- Grundriss eines 1933 - Grundriss eines Lexikons bildender Künstler und Kunsthandwerker in Oberschlesien von den Anfängen bis zur Mitte des 19. Jahrhunderts, hrg. Walther Krause, Bd. 1, Oppeln 1933.

- HAMPREL/AQUILAS 1999 - Wolf-Dieter Hamprel/Rohner Aquilas, Böhmisch-oberpfälzische Akanthusaltäre, Regensburg 1999.

- HETTWER 1937 - Josef Hettwer, Die Kirche von Kaubitz. Eine Führung, (w serii: Führer zu schlesischen Kirchen, 28), Breslau 1937.

- HOŁOWNIA 2008 - Ryszard Hołownia, Pod egida kardynała Fryderyka Heskiego. Barokizacja kościoła św. Jakuba w Nysie w 4 ćw. XVII wieku, [w:] Nysa. Sztuka w dawnej stolicy księstwa biskupiego, red. Ryszard Hołownia, Mateusz Kapustka, Wrocław 2008, s. 145-165.

- JUNGNITZ 1885 - Joseph Jungnitz, Geschichte der Dörfer Ober- und Nieder-Mois im Neumarkter Kreise, Breslau 1885 .

- KACZMAREK/BRZEZIŃSKI 2010 - Romuald Kaczmarek/Rafał Brzeziński, Dzierżoniów. Historia-Sztuka-Kultura. Przewodnik, Dzierżoniów 2010. 
- KALINOWSKI 1986 - Konstanty Kalinowski, Rzeźba barokowa na Śląsku, Warszawa 1986.

- KALINOWSKI 1995 - Konstanty Kalinowski, Warsztat barokowego rzeźbiarza, „Artium Quaestiones” 7 (1995), s. 103-140.

- KASTNER 1848 - August Kastner, Der Neisser Geschichts= Freund oder Geschichte des Fürstenthums und der Stadt Neisse, Bd. 1, Geschichte und Beschreibung der Pfarrkirche des heil. Jacobus zu Neisse, Neisse 1848.

- Katalog rzeźby 1987 - Katalog rzeźby barokowej na Śląsku, red. Konstanty Kalinowski, t. 1, Hrabstwo Kłodzkie, Poznań 1987.

- Katalog zabytków 1961A - Katalog Zabytków Sztuki w Polsce, red. Tadeusz Chrzanowski, Marian Kornecki, M. Zlat, T. VII, Województwo Opolskie, z. 1, Powiat brzeski, Warszawa 1967.

- Katalog zabytków 1961B - Katalog Zabytków Sztuki w Polsce, red. Tadeusz Chrzanowski, Marian Kornecki, T. VII, Województwo Opolskie, z. 2, Powiat głubczycki, Warszawa 1961.

- Katalog zabytków 1963 - Katalog Zabytków Sztuki w Polsce, red. Tadeusz Chrzanowski, Marian Kornecki, T. VII, Województwo Opolskie, z. 9, Powiat nyski, Warszawa 1963.

- KERN 2011 - Tina Kern, Die Altäre von Johann Lucas von Hildebrandt, Diplomarbeit, Universität Wien, Wien 2011.

- KĘBłOWSKI 1972 - Janusz Kębłowski, Nysa, (w serii: Śląsk w zabytkach sztuki, red. Tadeusz Broniewski, Mieczysław Zlat), Wrocław - Warszawa - Kraków - Gdańsk 1972.

- KNOBLICH 1862 - Augustin Knoblich, Kurze Geschichte und Beschreibung der zestörten St. Nicolaikirche vor Breslau, nebst ihrer Filiale St. Michaelis in Gross-Mochbern und der mit ihnen vereinten St. Corporis=Christi=Kirche in Breslau, Breslau 1862.

- KÖGLER 1841 - Joseph Kögler, Chroniken der Grafschaft Glatz, Bd. 1, Glatz 1841.

- KOLBIARZ 2010A - Artur Kolbiarz, Dekoracje Kaplicy Loretańskiej, [w:] Kościół klasztorny Wniebowzięcia NMP. Historia, stan zachowania, koncepcja rewitalizacji, red. Andrzej Kozieł (w serii: Historia Sztuki XXX, Acta Universitatis Vratislaviensis No 3253), Wrocław 2010, s. 460-470.

- KOLBIARZ 2010B - Artur Kolbiarz, Kwestia autorstwa rzeźb ołtarza głównego w kościele św. Jerzego w Ziębicach, [w:] Ziębice - miasto św. Jerzego. Dzieje i kultura dawnej stolicy książęcej, red. B. Czechowicz, Wrocław 2010, s. 161-170.

- KOLBIARZ 2011A - Artur Kolbiarz, Barokowy wystrój rzeźbiarski kościoła pielgrzymkowego w Bardzie i jego twórcy, [w:] Bardo. Skarby sztuki, red. Andrzej Kozieł, Legnica 2011, s. 113-123.

- KOLBIARZ 2011B - Artur Kolbiarz, Życie i twórczość Leopolda Straussa. Przyczynek do badań nad rzeźba barokową w Księstwie Ziębickim, „Roczniki Sztuki Śląskiej” 20 (2011), s. 87-113.

- KOLBIARZ 2012 - Artur Kolbiarz, Osiemnastowieczny ośrodek rzeźbiarski w Bardzie Śląskim, [w:] Splendor i fantazja. Studia nad rzeźbą rokokową w dawnej Rzeczypospolitej i na Śląsku, red. Paweł Migasiewicz, Warszawa 2012, s. 253-275.

- KOLBIARZ 2017 - Artur Kolbiarz, Między Praga a Legnica. Matthäus (Matthias) Knote. Śląski rzeźbiarz epoki baroku i jego warsztat, Legnica 2017.

- KOZIEŁ 2010 - Andrzej Kozieł, Ottarz kredensowy, [w:] Kościół klasztorny Wniebowzięcia NMP. Historia, stan zachowania, koncepcja rewitalizacji, red. Andrzej Kozieł (w serii: Historia Sztuki XXX, Acta Universitatis Vratislaviensis No 3253), Wrocław 2010, s. 148-151.

- KOZIEŁ 2013 - Andrzej Kozieł, Michael Willmann i jego malarska pracownia, (w serii: Historia Sztuki XXXIII, Acta Universitatis Vratislaviensis No 3463), Wrocław 2013.

- NOWAK 1994 - Romuald Nowak, Rzeźba śląska XVI-XVIII wieku. Katalog zbiorów, Wrocław 1994.

- NOWAK 2008 - Romuald Nowak, Barokowy wystrój rzeźbiarski Kaplicy Książęcej - próba odtworzenia, [w:] Opactwo cystersów w Lubiążu i artyści, red. Andrzej Kozieł (w serii: Historia Sztuki XXVI, Acta Universitatis Vratislaviensis No 3012), Wrocław 2008, s. 227-242.

- NOWAK/KOZIEŁ 2010 - Romulad Nowak/Andrzej Kozieł, Ottarze św. św. Jakuba i Filipa, [w:] Kościół klasztorny Wniebowzięcia NMP. Historia, stan zachowania, koncepcja rewitalizacji, red. Andrzej Kozieł (w serii: Historia Sztuki XXX, Acta Universitatis Vratislaviensis No 3253), Wrocław 2010, s. 445-450. 
- ORGANISTY 2007 - Adam Organisty, Dwie grupy rzeźb ślaskich z kręgu Georga Franza Pacáka i Ignaza Rohrbacha, [w:] Ślask i Czechy. Wspólne drogi sztuki. Materialy konferencji dedykowane Profesorowi Janowi Wrabecowi, red. Mateusz Kapustka, Andrzej Kozieł, Piotr Oszczanowski (w serii: Historia Sztuki XXIV, Acta Universitatis Vratislaviensis No 2953), Wrocław 2007, s. 240-246.

- ORGANISTY/SKRABSKI 2008 - Adam Organisty, Józef Skrabski, Rola i znaczenie projektów architektonicznych Matthiasa Steinla - przeglad dotychczasowych ustaleń, nowe spostrzeżenia, [w:] Opactwo cystersów w Lubiążu i artyści, red. Andrzej Kozieł (w serii: Historia Sztuki XXVI, Acta Universitatis Vratislaviensis No 3012), Wrocław 2008, s. 195-225.

- ORGANIŚCIAK/DUDZIAK/DZIEDZIC 1997 - Jerzy Organiściak/Tomasz Dudziak/Marcin Dziedzic, Ząbkowickie opowieści, cz. 3, Okolice Ząbkowic Ślaskich, monografia krajoznawcza, Ząbkowice Śląskie 1997.

- OSTOWSKA 1969 - Danuta Ostowska, Rzeźba ślaska 1650-1770. Katalog wystawy, Wrocław 1969.

- PATZAK 1930 - Bernhard Patzak, Archivalische und Kunsttopographische Beiträge der Grafschaft Glatz. Der Landecker Bildhauer Michael Ignatius Klahr, der Jungere (1727-1807), „Die Grafschaft Glatz“ 4 (1930), s. 6772.

- PEDEWITZ 1905 - Johann Felix Pedewitz, Historia Ecclesiastica Parochialis S. Jacobi Nissae, hrsg. Bernhard Ruffert, Neisse 1905.

- PÜHRINGER-ZWANOWETZ 1966 - Leonore Pühringer-Zwanowetz, Matthias Steinl, Wien-München 1966.

- SCHEMPER-SPARHOLZ 1998 - Ingeborg Schemper-Sparholz, Barockaltare in Osterreich - Mobel, Schaubuhne, Dankmal. Versuch einer Typologischen Ordnung, [w:] Triumph der Phantasie. Barocke Modelle von Hildebrandt bis Mollinarolo, Hg. Michael Krapf/Gerbert Frodl, Kat. Ausst. Osterreichische Galerie Belvedere, Wien 1998, s. 49-63.

- SCHWEDOWITZ 1909 - Walter Schwedowitz, Chronik der katholischen Gemeinde zu Reichenbach in Schlesien. Festschrift zum 750 jährigen Jubiläum ihres Bestehens, Reichenbach 1909.

- SCHWETER 1922 - Joseph Schweter, Wartha. Geschichte dieses Wallfahrtortes und der Wallfahrten dahin. Ein Beitrag zur Religions und Kulturgeschichte Schlesiens und der angrenzenden Länder, Schweidnitz 1922.

- SCHWETER 1939 - Joseph Schweter, Führer durh den Wallfahrtsort Wartha, Glatz 1939.

- SCHWETER 2001 - Joseph Schweter, Wartha (Bardo Śląskie). Historia miejscowości pielgrzymkowej i odbywajacych się do niej pielgrzymek, Bardo 2001.

- SITO 2016 - Jakub Sito, Rzeźba figuralna, [w:] Sztuka Polska, red. Jerzy Kowalczyk, t. V, Warszawa 2016, s. 353-421.

- SKOBEL 1922 - Paul Skobel, Camenz in Vergengenheit und Gegenwart, Camenz 1922.

- TISCHEROVÁ 2013 - Jana Tischerová, Matěj Václav Jäckel: sochař českého baroka 1655-1738, Praha 2013.

- TRATZ 1988 - Helga Tratz, Werkstatt und Arbeitsweise Berninis, „Römisches Jahrbuch für Kunstgeschichte“ 23/24 (1988), s. 395-483.

- UHLHORN 1927 - Anneliese Uhlhorn, Meister und Werke der Plastik des Spätbarock in Breslau (ca. 17001750), Berlin 1927.

- WITKOWSKI 2016 - Jacek Witkowski, Flamandzki rzeźbiarz w katedrze wrocławskiej, [w:] Katedra wrocławska na przestrzeni tysiąclecia. Studia $z$ historii architektury i sztuki, red. Romuald Kaczmarek/Dariusz Galewski, Wrocław 2016, s. 199-212.

- WITTKOWER 1974 - Rudolf Wittkower, The sculptor's Workshop. Tradition and Theory from Renaissance to the present, Glasgow 1974.

- WOJTYŁA 2012 - Arkadiusz Wojtyła, Idea odro militaris w sztuce barokowej krzyżowców z czerwona gwiazdą, (w serii: Historia Sztuki XXXII, Acta Universitatis Vratislaviensis No 3455), Wrocław 2012.

- WOLNÝ 1863 - Gregor Wolný, Kirchliche Topographie von Mähren, meist nach Urkunden und Handschriften, Bd. 5, Olmützer Diözese, Brünn 1863.

- ŻYDOWICZ 1986 - Małgorzata Żydowicz, Kaplica loretańska w kościele pocysterskim w Lubiążu, „Roczniki Sztuki Śląskiej" 14 (1986), s. 151-160. 


\section{The Genesis and Evolution of the Frame Altar in Silesia and the Works of Artists Related to the Artistic Centre in Bardo}

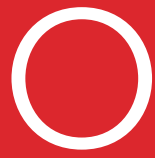

ver 30 years ago, Tadeusz Chrzanowski pointed to numerous frame-type altars in the area around the Silesian city of Bardo, recognising them as typical of the region. Although frame-type retabula were also popular in the rest of Silesia, the number of such works in the Duchy of Ziębice is de facto very high. On many occasions, authors of such reredoses were creators connected with the artistic centre in the city of Bardo, which was somewhat of a peculiarity. It was a small, borderland settlement located next to the main tract connecting Wrocław and Kłodzko, and concentrated around a pilgrimaging church which belonged to the Cistercians from Kamieniec Ząbkowicki. Throughout the $18^{\text {th }}$ century, it was home to numerous artists, mainly sculptors, but also carpenters, stonemasons and staffage painters, whose exceptionally intense activity allowed the Bardo workshops to dominate the artistic market in the Duchy of Ziębice, following a simultaneous weakening of the nearby sculpturing centres in Wrocław, Świdnica and Kłodzko. What is more, the workshops in Bardo clearly marked their presence in the ecclesiastical Duchy of Nysa, the County of Kłodzko and in the Wrocław area, sporadically operating also in Broumovsko, and Upper and Opavskie Silesia. The most predominant role in the Bardocentre was played by Andreas Ludwig Jäschke, who remained professionally active for over 50 years, and by the representatives of the artistic Hartmann dynasty: Johann Heinrich (who also enjoyed a long and professionally active life) and his sons Johann Nepomucene and Joseph. The peak of their artistic output can approximately 
be dated to the period between 1740 and 1790. The Bardo-based artists worked for such locally prominent patrons of the arts as the abbots of the Cistercian convents from Kamieniec Ząbkowicki and Henryków, the Jesuits from Kłodzko and Nysa, the canons from Wrocław,and the Benedictines from Broumovsko.

For a long time, the central altar in the pilgrimaging church in Silesian Bardo (1715) or the retabulum in the post-Jesuit church in Nysa (1691) were perceived as the archetype of the frame-type reredos in Silesia. It was Ryszard Hołownia who revolutionised the status of the research, pointing to the non-existent high altar of the Church of St. Jacob in Nysa (1677-1679), erected thanks to the endeavours of Cardinal Friedrich von Hessen-Darmstadt. This mysterious work was so innovative that similar forms and designs would not be seen in Silesia and the whole of Central Europe until a few decades later. Equally surprising was the lack of imitation of the Nysa retabulum in the art of the region.

Silesian frame-type altars began to appear in greater numbers after 1700, combining the experience of the transalpine art (acanthus epitaphs and retabula) with dramatizing motifs derived from Italy (angels carrying the altar painting). Initially, their appearance varied and depended on individual artistic conceptions. It was the artists gathered around the monastic workshop in Lubiąż who contributed to the development of a full-scale programme of a frame-type retabulum. At first, under the guidance of Matthias Steinl, they introduced acanthus altars in the region. And then, they popularised the motif of angelic statues carrying the painting, possibly under the guidance of Michael Lichtner, as mentioned in the archives.

An early example of a frame-type altar in Silesia is the reredos within the Church of Corpus Christi in Wrocław (1699), authored by Sulpicius Gode. In the Duchy of Ziębice, frame-type reredoses were present in the works by artists directly preceding the heyday of the Bardo centre: Leopold Strauss, Anton Jörg and Georg Schenck. Archival materials indicate that Strauss made the high altar of the pilgrimaging church in Bardo(1714-1715 and 1720-1721). After his death and the emigration of the others, the leading role in the region was taken by artists working in Bardo, who eagerly applied the frame-typealtar. They already used more standardised and unified forms, inspired by the art of the Archduchy of Austria in the first half of the $18^{\text {th }}$ century (and, above all, the works by Johann Lukas von Hildebrandt and Antonio Beduzzi). Another common practice they applied was the expansion of altar pedestal areas by adding gates. One may even venture to state that the increased popularity of frame-type reredoses in the region of Kamieniec Ząbkowickistemmed from the high status of the altar in Bardo, which constituted a frame for the venerated statue of Mother of God. 